\title{
Review \\ Wen Dan Tang: A Potential Jing Fang Decoction for Headache Disorders?
}

\author{
Saroj K. Pradhan 1,2,3,*(D), Yiming Li ${ }^{1,2,3}$, Andreas R. Gantenbein ${ }^{4}$, Felix Angst ${ }^{5}$, Susanne Lehmann 5 \\ and Hamdy Shaban 6
}

check for updates

Citation: Pradhan, S.K.; Li, Y.;

Gantenbein, A.R.; Angst, F.;

Lehmann, S.; Shaban, H. Wen Dan

Tang: A Potential Jing Fang

Decoction for Headache

Disorders? Medicines 2022, 9, 22.

https://doi.org/10.3390/

medicines 9030022

Academic Editor: James David

Adams

Received: 30 November 2021

Accepted: 3 March 2022

Published: 4 March 2022

Publisher's Note: MDPI stays neutral with regard to jurisdictional claims in published maps and institutional affiliations.

Copyright: (C) 2022 by the authors. Licensee MDPI, Basel, Switzerland. This article is an open access article distributed under the terms and conditions of the Creative Commons Attribution (CC BY) license (https:// creativecommons.org/licenses/by/ $4.0 /)$.
1 Research Department Rehaklinik, TCM Ming Dao, ZURZACH Care, 5330 Bad Zurzach, Switzerland; y.li@tcmmingdao.ch

2 Research Department, Swiss TCM Academy, 5330 Bad Zurzach, Switzerland

3 Research Department, Nanjing University of Chinese Medicine, Nanjing 210029, China

4 Neurology \& Neurorehabilitation Department Rehaklinik, ZURZACH Care, 5330 Bad Zurzach, Switzerland; andreas.gantenbein@zurzachcare.ch

5 Research Department Rehaklinik, ZURZACH Care, 5330 Bad Zurzach, Switzerland; felix.angst@zurzachcare.ch (F.A.); susanne.lehmann@zurzachcare.ch (S.L.)

6 Department of Private Psychiatry Clinic of UPK, University Psychiatric Clinics, 4002 Basel, Switzerland; hamdy.shaban@upk.ch

* Correspondence: s.pradhan@tcmmingdao.ch

\begin{abstract}
Background: Chinese herbal medicine is considered relatively safe, inexpensive, and easily accessible. Wen Dan Tang (WDT), a Jing Fang ancient classical Chinese herbal formula with a broad indication profile has been used for several centuries in China to treat various illnesses. Question: Are there evidence-based clinical trials that show that WDT has a significant impact on the treatment of various diseases, especially in patients with migraine and tension-type headaches (TTH)? Methods: This study is based on an online database search using PubMed, Medline, Cochrane Library, AcuTrials, Embase, Semantic Scholar, Jstor, internet research, and review of ancient and modern Chinese medical textbooks regarding WDT and its compounds. Results: There were no studies on WDT in migraine and TTH; therefore, this work gathers and describes data for every single compound in the formula. Conclusion: This study suggests that the bioactive compounds found in WDT composition show potential in treating patients with neurological, psychiatric disorders, cardiovascular diseases, metabolic syndrome, and digestive disorders. Some coherence between WDT in headache reduction and improvements in the quality of life in patients with migraines and TTH could be evaluated, showing positive results of WDT in these patients.
\end{abstract}

Keywords: Chinese herbal medicine; Wen Dan Tang; traditional Chinese medicine; headache disorders; migraine; tension-type headache

\section{Introduction}

The implementation of Traditional Chinese Medicine (TCM) for the prevention and treatment of numerous medical conditions has lasted for thousands of years, predominantly in China and Asia, but also in the Western world in the last few decades.

Wen Dan Tang (WDT), also known as "Warm the Gallbladder decoction", is a classical famous Chinese herbal formula containing eight components derived from the book Treatise on Three Categories of Pathogenic Factors: Pinellia ternata (Thunb.) Makino (Ban Xia), Bambusa tuldoides Munro (Zhu Ru), Citrus aurantium L. (Zhi Shi), Citrus reticulata Blanco (Chen Pi), Glycyrrhiza uralensis Fisch (Gan Cao), Poriae sclerotium cocos albae (Fu Ling), Zingiber officinale Roscoe (Sheng Jiang), and Ziziphus jujuba Mil (Da Zao) (Table 1) [1,2]. 
Table 1. WDT herbal components species and function.

\begin{tabular}{|c|c|c|}
\hline Species & Function & Reference \\
\hline $\begin{array}{c}\text { Pinelliae Rhizoma } \\
\text { (Pinellia ternata (Thunb.) }{ }^{1} \text { Makino) }\end{array}$ & $\begin{array}{c}\text { Ceases cough, dissolves phlegm, dries dampness, stops vomiting, } \\
\text { possesses antitumor effects }\end{array}$ & [3] \\
\hline $\begin{array}{l}\text { Caulis Bambusae In Taenia sp. } \\
{\text { (Bambusa tuldoides Munro })^{1}}^{1}\end{array}$ & $\begin{array}{l}\text { Arrests vomiting, alleviates fever, abdominal pain, diarrhea, chest } \\
\text { diaphragm inflammation, has antifatigue attributes, regulates } \\
\text { hypertension and hyperlipidemia, reduces aggravation }\end{array}$ & {$[4,5]$} \\
\hline $\begin{array}{l}\text { Fructus Aurantii Immaturus } \\
\quad{\text { (Citrus aurantium L. })^{1}}^{1}\end{array}$ & $\begin{array}{l}\text { Helps gastrointestinal disorders, is anti-coagulation, eliminates food } \\
\text { stagnation by guiding the Qi downwards, has antianxiety properties }\end{array}$ & {$[6,7]$} \\
\hline $\begin{array}{l}\text { Citri reticulate Pericarpium } \\
{\text { (Citrus reticulata Blanco })^{1}}^{\text {Cita }}\end{array}$ & $\begin{array}{c}\text { Dissolves phlegm, dries dampness, promotes Qi, strengthens spleen, } \\
\text { has antiasthmatic characteristic }\end{array}$ & [8-10] \\
\hline $\begin{array}{l}\text { Glycyrrhizae Radix et Rhizoma } \\
\text { (Glycyrrhiza uralensis Fisch) }^{1}\end{array}$ & $\begin{array}{l}\text { Tonifies Qi and the spleen, harmonizes the action of all herbs in a } \\
\text { prescription, and eliminates the toxicity of herbs }\end{array}$ & {$[11,12]$} \\
\hline $\begin{array}{c}\text { Poria Cocos } \\
{\text { (Poriae sclerotium cocos albae })^{1}}\end{array}$ & $\begin{array}{l}\text { Strengthens the spleen and harmonizes the stomach, has antianxiety } \\
\text { properties, is calmative, has a soothing diuretic effect }\end{array}$ & {$[13,14]$} \\
\hline $\begin{array}{l}\text { Zingiberis Rhizoma } \\
\text { (Zingiber officinale Roscoe) }^{1}\end{array}$ & $\begin{array}{l}\text { Has an antiemetic effect, alleviates pain, harmonizes the stomach and } \\
\text { spleen, warms the core and the lungs, removes cold }\end{array}$ & {$[15,16]$} \\
\hline $\begin{array}{c}\text { Jujubae Fructus } \\
(\text { Ziziphus jujuba Mil) }\end{array}$ & $\begin{array}{l}\text { Nurtures the blood, has a calmative effect, promotes Qi, tonifies the } \\
\text { stomach and spleen, regulates digestive system, reduces the toxicity } \\
\text { of herbs }\end{array}$ & {$[17,18]$} \\
\hline
\end{tabular}

WDT origins and functions listed in Table $1 .{ }^{1}$ The accepted Nomenclatural name of the species validated by www.theplantlist.org (accessed on 19 May 2021).

Classically, WDT is a TCM prescription for disorders of the spirit and has been used for 100 years to treat symptoms such as schizophrenia. Deng and $\mathrm{Xu}$ have shown that WDT may have some positive short-term antipsychotic effects compared to placebo or no treatment. Nevertheless, combining WDT with an antipsychotic reduced the adverse effects of antipsychotics [19]. Clinically, WDT is used to treat psychiatric disorders (such as schizophrenia, major depressive disorder, and anxiety), insomnia, stroke, digestive disorder, metabolic syndrome, and cardiovascular disease [19-29]. The application of WDT in various syndromes is illustrated in Table 2 . Additionally, WDT is considered relatively safe, economical, and obtainable [19].

Table 2. Application of WDT in various syndromes.

\begin{tabular}{|c|c|c|}
\hline References & Title & Syndrome \\
\hline [24] & Treatment of Insomnia with Traditional Chinese Herbal Medicine. & \multirow{2}{*}{ Insomnia } \\
\hline [27] & Wendan decoction for primary insomnia. & \\
\hline$[30]$ & $\begin{array}{c}\text { Wen-Dan Decoction Improves Negative Emotions in Sleep-Deprived Rats by } \\
\text { Regulating Orexin-A and Leptin Expression. }\end{array}$ & Negative Emotions \\
\hline [26] & $\begin{array}{c}\text { Consistent Efficacy of Wendan Decoction for the Treatment of Digestive } \\
\text { Reflux Disorders. }\end{array}$ & Digestive disorder \\
\hline$[31]$ & $\begin{array}{l}\text { Wendan decoction for dyslipidaemia: Protocol for a systematic review and } \\
\text { meta-analysis. }\end{array}$ & Dyslipidaemia \\
\hline [23] & $\begin{array}{l}\text { Metabolomic investigation into molecular mechanisms of a clinical herb } \\
\text { prescription against metabolic syndrome by a systematic approach. }\end{array}$ & \multirow{2}{*}{ Metabolic syndrome } \\
\hline [25] & $\begin{array}{l}\text { Efficacy of the wen dan decoction, a Chinese herbal formula, for } \\
\text { metabolic syndrome. }\end{array}$ & \\
\hline
\end{tabular}


Table 2. Cont.

\begin{tabular}{ccc}
\hline References & Title & Syndrome \\
\hline & & Psychiatric disorders \\
\hline$[22]$ & Behavioural screening of zebrafish using neuroactive traditional Chinese \\
medicine prescriptions and biological targets. & Major depressive disorder \\
\hline$[19]$ & Wendan decoction (Traditional Chinese medicine) for schizophrenia. & Schizophrenia \\
\hline$[21]$ & Effects of Wen Dan Tang on insomnia-related anxiety and levels of the & Anxiety \\
\hline$[32]$ & Wrain-gut peptide Ghrelin. & Stroke \\
\hline$[28]$ & Systems Pharmacology Dissection of Traditional Chinese Medicine Wen-Dan & Cardiovascular Diseases \\
\hline
\end{tabular}

Application of WDT in various syndromes listed in Table 2.

Sun Si Miao (580-682 A.D.), who was honored as the "King of Herbal Medicine", completed a 30-volume encyclopedia entitled Essential Recipes for Emergent Use Worth A Thousand Gold, including 4500 Chinese herbal formulae and a treatise on medical practice [33]. He describes in the mentioned encyclopedia, among other things, the components, properties, function, and preparation of WDT [34]. The classification method of disease disorders in this compendium derives from the Yellow Emperor's Inner Canon, Treatise on Cold Pathogenic and Miscellaneous Diseases, and General Treatise on Causes and Manifestations of All Diseases [35].

In 2018, Sun Si Miao's WDT was listed in the Catalogue of Ancient Classics Formulae (ACF) among the other 99 ACFs by the National Administration of Traditional Chinese Medicine [1].

WDT is available as a classical Chinese decoction, granules, pills, or hydrophilic concentrate. This hydrophilic concentrate from the Dr. Noyer AG/TCM pharmacy in Switzerland is produced according to the Kumagawa method. Each substance is preserved for one night in purified water and is then extracted with the so-called Kumagawa-Extractor. During this process, the substances are dissolved as in a decoction process. At the end of the procedure, glycerin is added to ensure the durability of the hydrophilic concentrate. Only boiled water as a solvent is used in the Kumagawa-Extractor. The extract obtained is therefore very similar to decoction but contains more API agents. This means that smaller quantities can be administered for an identical result compared to decoction [36].

Traditionally, the compounds of WDT are immersed in $1200 \mathrm{~mL}$ water for $30 \mathrm{~min}$ and then boiled in a decoction pot. After the boiling process, the decoction simmers for 30 to $40 \mathrm{~min}$. The extract is filtered, and usually the dosage of $300 \mathrm{~mL} /$ day is administrated for drinking. Zhang et al. stated in their study that the extraction of WDT applying the UHPLCQQQ-MS/MS method was more beneficial than the traditional extraction technique with water because the boiling process negatively affects the stability of the molecule gingerol. In addition, instead of methanol, acetonitrile was utilized for the chromatography, and therefore, better isolation of the individual components could be achieved. The complete extraction method could be performed within $30 \mathrm{~min}$ in the lab. This procedure is thus not more time-consuming than the traditional method, and more pure gingerol extracts can be obtained with it [2].

Headache disorders (HD) affect all ages and genders and have become a widespread public health burden [37]. Headache not only influences the individuals' constricted quality of life (QoL) and health but also entails enormous economic costs [38].

The present valid International Classification of Headache Disorders (ICHD-3) published in 2018 [39] distinguishes between primary and secondary headaches, as well as neuropathies and facial pain, with more than 300 different types of headache, presented in a hierarchical structure for diagnosis. The most prevalent $\mathrm{HD}$ is migraine and tension-type headache (TTH). 
According to TCM, a person is healthy when Yin and Yang, vital energy (Qi), and blood in the body are in balance and the Qi can flow freely in the conduit pathways. All complaints arise by disorders aroused by blockages of Qi and/or blood or lack of Qi and/or blood and when Yin and Yang in the body become unbalanced [40].

Endogenous factors for headaches from the point of TCM's view are mostly hyperactivity of liver Yang, deficiency of Qi and blood, spleen, kidney weakness, and ascending stagnated fire to the brain [41].

The Western medicine pharmacotherapy treatment for HD includes acute and preventive medications [42]. In comparison to Western medicine, the treatment with WDT can hypothetically be applied for all types of HD.

Additionally, there have been numerous research studies showing WDT usage in the treatment of various diseases that might lead to HD [19-21,23-27,29].

Thus, WDT might be beneficial in the prophylactic treatment for migraine with few adverse effects. The most common adverse events reported by Huang et al. in their metaanalysis were loose stool, dizziness, poor appetite, fatigue, and xerostomia. However, the observed AEs were mild [25].

From our clinical experience over the years, a very large number of patients reported an improvement in their HD and their QoL after WDT intake. Therefore, it was our approach to review the literature regarding the application of WDT in migraine and TTH. In our review, we questioned if there are evidence-based clinical trials that show that WDT has a significant impact on the treatment of HD, especially migraine and TTH.

\section{Methods}

\subsection{Search Strategy}

Research data were acquired from PubMed, Medline, Cochrane Library, AcuTrials, Embase, Semantic Scholar, Jstor, and the internet; additionally, ancient and modern Chinese medical textbooks regarding WDT were reviewed, and studies based on our aim were selected.

Search terms were as follows: headache disorders, Wen Dan Tang, Wen Dan Tang pharmacological reaction, migraine, tension-type headache, Wen Dan Decoction, WDT mechanisms of action.

\subsection{Inclusion Criteria}

Inclusion criteria contained reviews and peer-reviewed research articles exploring the effects of WDT.

\section{Results}

Systematic reviews and peer-reviewed research articles were evaluated for this study. The results were analyzed, classified, and summarized. There were no studies on WDT in migraine and TTH; therefore, results and studies for the single compounds are described instead.

\section{Discussion}

In ancient China, WDT was applied to arouse courage in a person. According to TCM, WDT's function is to remove heat-phlegm and harmonize the gallbladder and the stomach. The effects of WDT are sedative, anxiolytic, anti-depressive, regulate the flow of vital energy (Qi), expectorant, heat-eliminating, harmonize the stomach, and encouragement $[43,44]$. As the gallbladder is the source of courage in TCM, the phlegm heat may cause anxiety, restlessness, insomnia, and agitation. The flow of the rebellious Qi in the stomach may cause stomach upset. WDT clears phlegm and heat, regulates Qi, harmonizes the gallbladder and the stomach, and calms the spirit [45].

Modern scientific research provided evidence that WDT contains compounds including flavonoids, phenols, alkaloids, triterpenoid organic acid, polysaccharides, and phosphodiesterase inhibitors (Table 3), which have been found to possess neuroprotective, 
neuromodulation, anti-mutagenic, antioxidant, antiemetic, antithrombotic, antipyretic, and anti-inflammatory effects [2,30,46-52].

Table 3. A list of the bioactive compounds contained in WDT, as defined by Zhang et al. [2].

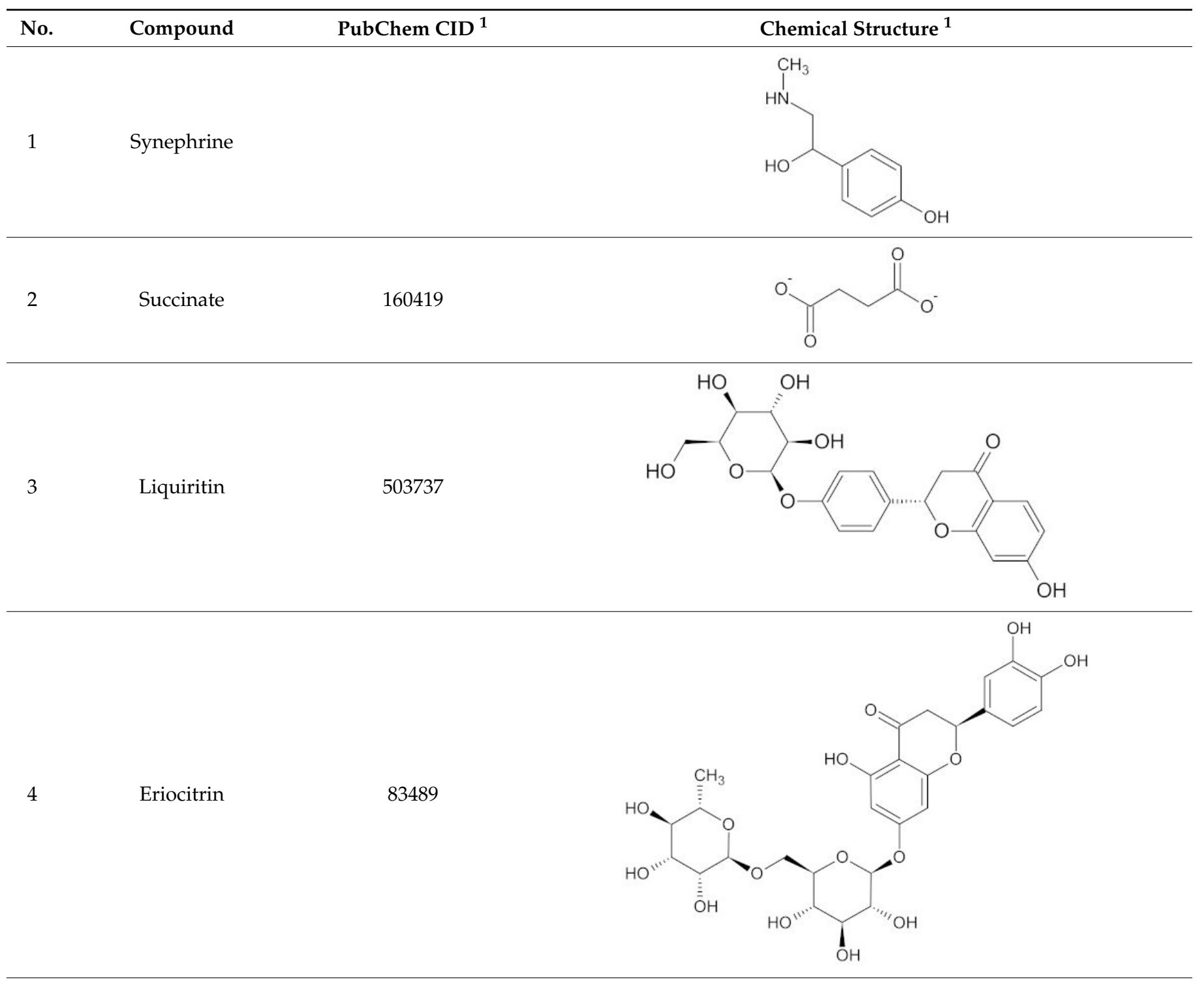

$5 \quad$ Rutin

5280805
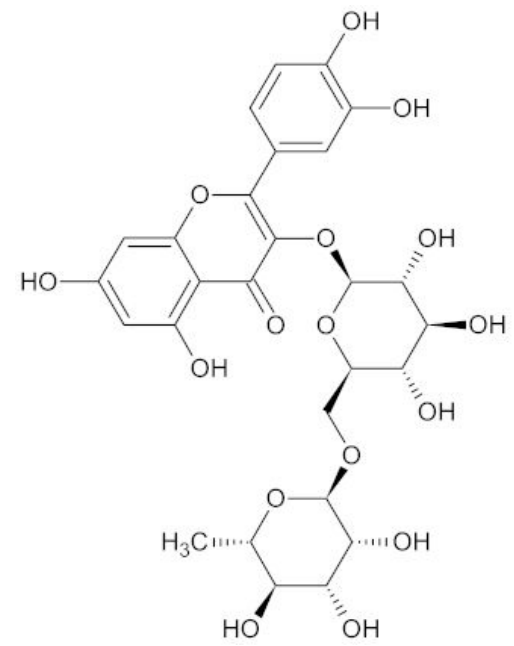
Table 3. Cont.

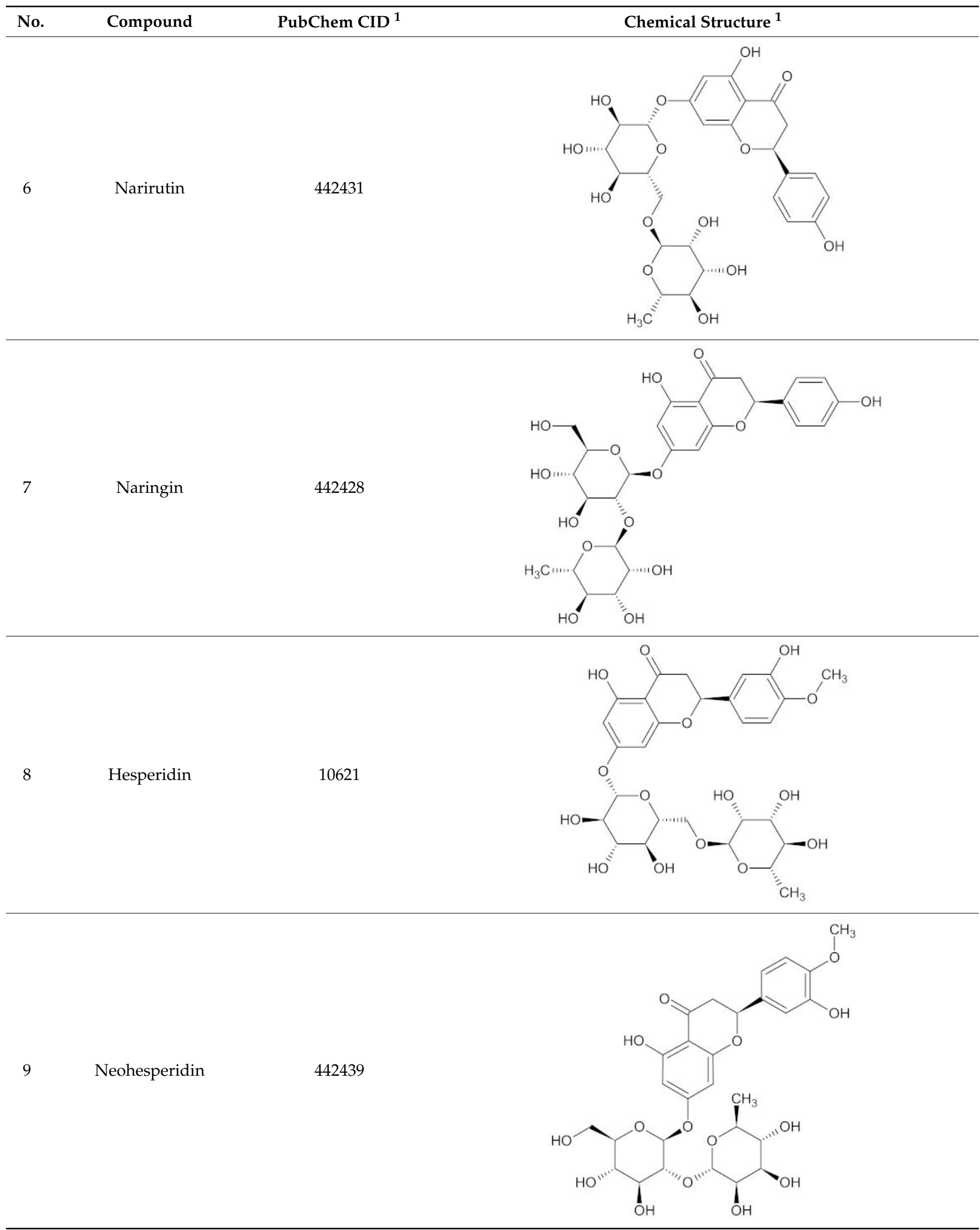


Table 3. Cont.

\begin{tabular}{llcl}
\hline No. & Compound & PubChem ID $^{1}$ & Chemical Structure $^{1}$ \\
\hline 0 & Liquiritigenin & 114829
\end{tabular}

11 Isoliquiritin

5318591
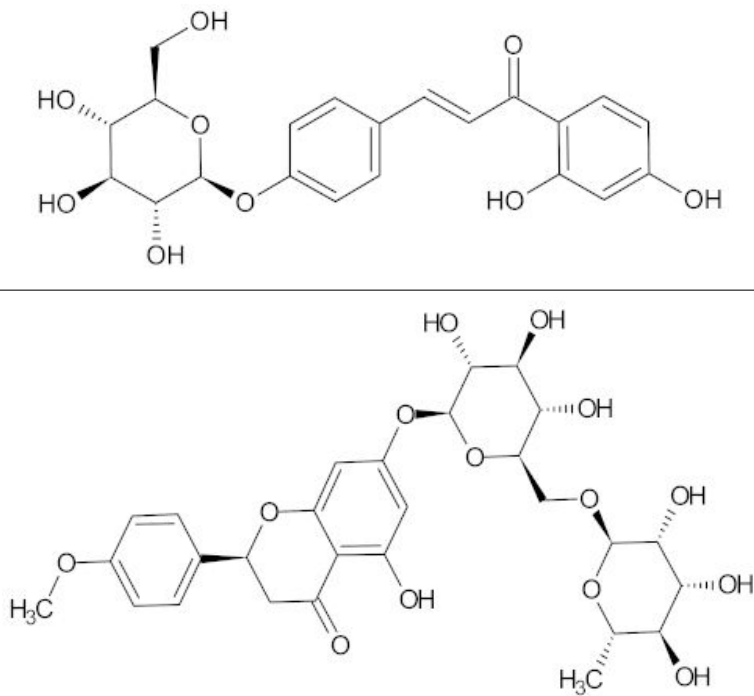

13

Poncirin

442456

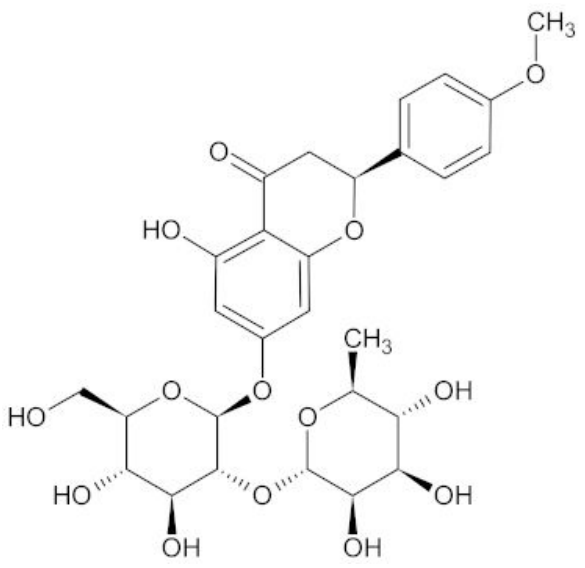

442793<smiles>CCCCC[C@H](O)CC(=O)CCc1ccc(O)c(OC)c1</smiles>

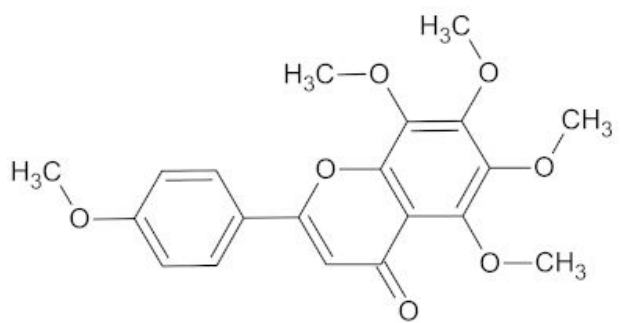


Table 3. Cont.

No. Compound 18 PubChem CID ${ }^{1}$

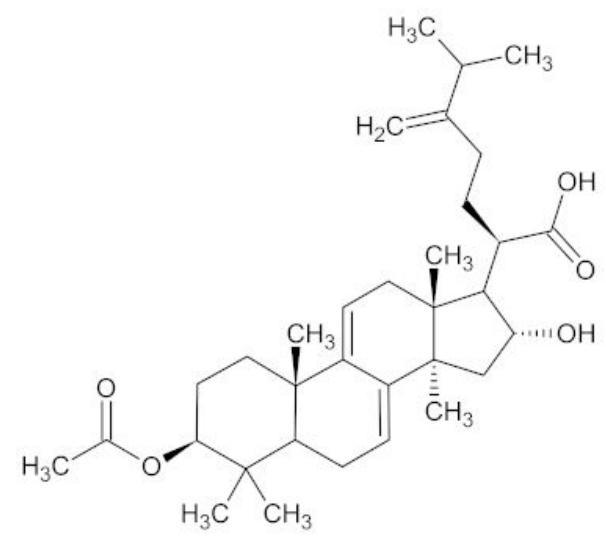

A list of the bioactive compounds contained in WDT, as defined by Zhang et al., is listed in Table 3 [2]. ${ }^{1}$ All chemical structures were redrawn with (ACD/ChemSketch Freeware) [53] after being retrieved from National Centre for Biotechnology Information (2020). PubChem Compound Summary for CID number above from https:/ / pubchem.ncbi.nlm.nih.gov/compound (Retrieved 25 September 2020).

\subsection{Alkaloids}

Alkaloids are biologically active, organic, nitrogen-containing compounds that widely occur in various plant families such as the nightshade, poppy, and buttercup families [54]. The nitrogen atom(s) of true alkaloids is usually within a heterocyclic ring and derives from an amino acid. Alkaloids are often optically active, mostly left-handed, and, in the pure form, normally colorless crystalline substances [55].

The bioactive alkaloid within WDT is synephrine [2,30], which is a phenylethylamine derivative [56], also found in bitter orange (Citrus aurantium L. from the Rutaceae family) [57]. There are three isomeric forms of synephrine: $m$-synephrine, $\mathrm{p}$-synephrine, and o-synephrine. P-synephrine may act on alpha-1 and beta-3 adrenoreceptors [58]. It causes a stimulation through its direct binding to the alpha-adrenoreceptor, which leads to a contraction of the smooth muscles, thus causing vasoconstriction of the blood vessels, e.g., 
in the mucous membranes [59]. The rhinitis-induced secondary headache can, for instance, be reduced by the bioactive substance synephrine [60].

Synephrine belongs to the trace amines synthesized from aromatic amino acids in mammals [61]. An increased level of plasma trace amines was shown to occur in both cluster headache and migraine patients. The alteration in biogenic amine metabolism is one of the characteristics of primary headache sufferers [62]. Additionally, dopamine and trace amines' abnormal levels may contribute to the metabolic cascades that predispose headaches' occurrence [63].

Migraine is a neurovascular disorder related to the impairment of the cerebral nerves and blood vessels. Calcitonin gene-related peptide (CGRP) is the most effective peptidergic vasodilator of peripheral and cerebral blood vessels. CGRP is unleashed to sensory nerves during severe migraine outbreaks and, for a long time, has been considered to play a very important role in the pathophysiology of migraine. Farooqui T. reported a hypothetical molecular mechanism underlying cluster and/or migraine headaches. One of the most accepted mechanisms indicates that the release of CGRP results in vasodilation and cranial meningeal stimulation, causing primary headache [64]. As synephrine has been described to exert vasoconstrictive effects, it can be assumed that the consumption of synephrine could contribute to the reduction in the so-caused primary headaches.

The beta-3-adrenoreceptors are located in white and brown adipocytes [65] and play an important role in lipolysis and thermogenesis [59]. Synephrine activates the betaadrenoreceptor and elevates cyclic AMP (cAMP) levels due to adenylyl cyclase activation. The rise in cAMP levels, which might lead to migraine [66], leads to a surge in the release of fatty acids from adipose tissue and consequently promotes fat oxidation by increasing thermogenesis [67]. In a study published in the British Journal of Clinical Pharmacology by Gutiérrez-Hellín et al., p-synephrine showed a significant increase in fat burning at low-to-moderate exercise intensity without changes in heart rate or blood pressure [68-70].

P-synephrine is chemically similar to ephedrine, but in contrast to synephrine, ephedrine exhibits bindings to beta-1, beta-2, and beta- 3 receptors, leading to more adverse effects such as hypertension, tachycardic arrhythmias, hyperthyroidism, and an increase in respiratory rate [71]. Consequently, p-synephrine cannot be categorized as a stimulant [72,73].

P-synephrine consumption at recommended levels has been shown to be safe [57]. The low toxicity of p-synephrine and Citrus aurantium L. extracts in mice tested in an in vitro model at a high dose was shown by Arbo et al. and Rossato et al. to cause low or insignificant cardiotoxicity [74-77].

In a randomized controlled trial, Bond et al. compared the effect on headache frequency in women with comorbid migraine and overweight/obesity and concluded that weight loss would improve the QoL of the affected person and might be promising in reducing migraine headaches' frequency [78].

Kaats et al. provided evidence in a randomized, double-blinded, placebo-controlled study that a chocolate-flavored chew with a bitter orange extract containing p-synephrine could significantly suppress appetite, increase energy, and decrease food intake without adverse effects [79].

Depression and anxiety are very often seen as a comorbidity in HD patients [80-83]. Kim et al. outlined the antidepressant-like activity in p-synephrine [84], and the effects of Citrus aurantium $\mathrm{L}$. essential oil regarding the treatment of anxiety and depression has been discussed in several studies [85-90]. Citrus aurantium L. is an essential oil with a potential benefit for pain reduction and QoL improvement for HD patients.

\subsection{Phenols}

Phenol is a hydroxybenzene, which is an aromatic organic compound. In pure form, it is a colorless-to-white crystalline [91].

The substances contained in WDT are gingerols [2,30], a group of volatile phenolic compounds $[92,93]$. Gingerols are categorized according to their alkyl chain length, e.g., (6)gingerol, (8)-gingerol, and (10)-gingerol, where (6)-gingerol is the most abundant compound 
segregated from ginger, while other gingerols are present in lower concentrations [93,94]. Chemically, gingerols are methoxy-substituted phenols with an alkyl side-chain that carries one keto and one hydroxy group each [95].

Gingerols are known to have beneficial medicinal properties and exert remarkable pharmacological and physiological activities. Several pre-clinical studies have supported their role in treating several disorders such as diabetes, pain, fever, and inflammation [93,96].

A current hypothesis is that oxidative stress plays a major role in migraine pathogenesis [97-99]. Studies have demonstrated that gingerols possess a high antioxidant effect by inhibiting superoxide and nitric oxide production and suppressing lipid peroxidation [93,96,100-106]. It can be assumed that the established anti-oxidative activity of gingerols and specifically of (6)-gingerol might be advantageous for the treatment of HD $[49,93,107]$.

A connection between prostaglandin and migraine-like attacks has already been shown $[108,109]$. Gingerols have a function as a suppressor of proinflammatory cytokines, inhibiting prostaglandin and leukotriene biosynthesis [110-112], and might therefore be a suitable antipyretic for prostaglandin-induced HD treatment $[49,113]$.

Studies in human liver cell lines indicate that (6)-gingerol decreases inflammation and oxidative stress by decreasing mRNA levels of inflammatory factor interleukin 6 (IL-6), interleukin 8, and serum amyloid A1 [114]. In vivo models with treatment and topical application of (6)-gingerol to mice exhibited anti-inflammatory activity as well $[115,116]$. The reduction in inflammatory factors was shown to be an antidepressant effect in an animal model of depression $[117,118]$. Furthermore, gingerols play an important role in influencing the absorption of glucose by increasing cell surface distribution of the glucose transporter Type 4 (GLUT-4) protein [119,120], a glucose transporter that regulates the insulin-dependent glucose uptake in skeletal muscles [121,122]. Insulin attaches to the alpha-subunit of the insulin receptor and thus ensures an increase in phosphoinositide 3-kinase (PI3K. The signal transmission at the GLUT-4 caused by PI3K binding to the cell membrane results in an increase in glucose transport into the muscle cells $[123,124]$.

A typical adverse effect of a hypoglycemic state is headache. The ICHD-3 classifies this HD as a headache attributed to other metabolic or system disorder ICHD-3 A10.8.2 [39]. A hypoglycemic state can be prevented by the increased absorption of glucose [125].

Many HD patients suffer from nausea and emesis before or during their migraine attacks [126,127]. Studies showed that gingerol could suppress emetic signal transmission in vagal afferent neurons by inhibiting the 5-hydroxytryptamine 3 as well as being antagonistic to acetylcholine receptors [128-134]. The efficacy of ginger compounds on the prevention of nausea and vomiting of various origins, albeit with the limits of the chemical stability of the gingerol compounds, was highlighted in a systematic review of randomized controlled trials [135]. Moreover, gingerols have been shown to selectively inhibit the inducible form of cyclooxygenase-2 (COX-2) but not the constitutive form cyclooxygenase- 1 (COX-1). As inhibition of COX-1 is associated with gastrointestinal side effects; selective inhibition of COX-2 might help minimize these side effects [136]. Hence, using ginger to reduce nausea and emesis in HD patients would be a suggestive approach.

Gingerols have been shown to have further bioactive effects, such as being cardiotonic, antiemetic, anti-inflammatory, antitumor-promoting, anti-platelet aggregation in migraine [118], antifungal, analgesic, and antibacterial [125,137-142]. According to Zick et al., healthy humans can tolerate (6)-, (8)-, and (10)-gingerols till $2000 \mathrm{mg}$ [143].

\subsection{Isoflavonoids}

Isoflavonoids are secondary metabolites of plants and a subclass of flavonoids [144]. They are defined by a B-ring attached at the C-3 position of their C-ring and are derived from the flavonoid biosynthesis pathway via liquiritigenin or naringenin [145]. The Isoflavonoid group includes isoflavans, isoflavonones, isoflavones, rotenoids coumestans, and pterocarpans. Isoflavonoid compounds have biological effects via the estrogen receptor. They are natural selective estrogen receptor modulators, have a structural similarity to 17- $\beta$ - 
estradiol [146], bind especially to the $\beta$-estrogen receptor in the brain, have osteo-protective effects, and alleviate menopausal symptoms [147]. Migraine attacks are intensified due to increased estrogen levels in women [148]. WDT contains isoflavones [2,30] that could improve migraine caused by elevated estrogen levels and/or prevent menstrual-associated migraine [149,150].

Besides several flavonoids, WDT also contains isoflavonoids such as liquiritin and liquiritingenin [2,30]. Liquiritin is the 4'-O-glucoside of flavanone liquirtingenin [151]. Liquiritin and Liquirtingenin are characterized by their antioxidant, anti-inflammatory, anti-rheumatoidal, and neuroprotective effects [152-154].

\subsection{Liquiritin, Liquiritingenin, and Isoliquiritigenin}

Radix Glycyrrhizae (RG) is the rhizome of Glycyrrhiza ruralness Fisch., Glycyrrhiza inflate Bat., or Glycyrrhiza glabra L. from Leguminosae/Fabaceae, which are widely distributed in the northeast and northwest of China. The dried roots and rhizomes (GU), commonly known as licorice in Pharmacopeias $[155,156]$, are one constituent of WDT. Licorice was shown to have antitussive, expectorant, and antipyretic effects and is mostly used for its therapeutic effects in alleviating cough, pharyngitis, bronchitis, and bronchial asthma $[151,157,158]$.

The sweet-tasting bioactive saponin (Glycyrrhizin) is present in all Glycyrrhiza species. Glycyrrhizin can provoke hypertension, sodium salt and water retention, and potassium ion levels reduction [159,160]. Higher doses of glycyrrhizic acid (400 mg/day) have risky side effects, including cardiac dysfunction, edema, and hypertension [161]. Nevertheless, medicinal plants have beneficial chemical constituents, Liquiritin (LT), Liquiritingenin (LTG), and Isoliquiritigenin (ISL), that produce physiological changes of various health benefits [151,162]. There are at least 400 different chemical compounds in RG along with triterpenoid saponins, flavanones, chalcones, coumarins, and their glycosides [151,158,163,164].

The main bioactive flavonoid compounds in RG, LTG, and ISL were identified and isolated from the crude extract of Glycyrrhiza uralensis $[165,166]$. ISL demonstrates antioxidant, anti-inflammatory, antitumor, and hepatoprotective activities. Additionally, LTG is an estrogenic compound that acts as a selective agonist for the $\beta$-subtype estrogen receptor [151]. Moreover, derivatives of ISL and LTG were shown to have in vivo anti-diabetic activity [167].

LTG pre-treatment significantly reduced the LPS-induced depression symptoms in an animal model with a decrease in the levels of the proinflammatory cytokines in serum and hippocampus compared with the control LPS group [168]. LTG has been shown to lower the expression of brain-derived neurotrophic factor (BDNF) and p-TrkB (tropomyosin receptor kinase B) [169], indicating that the antidepressant and antianxiety activities of LG/LTG might be due to anti-inflammatory and BDNF/TrkB pathways [168]. In the hippocampus of the animal model of depression, LG upregulated the concentrations of 5-hydroxytryptamine (serotonin; 5-HT) and norepinephrine (NE) and acted on the PI3K/Akt/mTOR-mediated BDNF/TrkB pathway in the hippocampus [151,169].

These facts suggest that LTG could ease depressive-like symptoms in the mice model of depression [169]. Additionally, other reports indicated that LTG and ISL might act as major MAO inhibitors, which in turn are beneficial in the treatment of anxiety and depression and consequently as a preventive measure for HD [169-171].

In addition, ISL and LTG showed effective prevention of glutamate-induced toxicity by attenuation of mitochondrial malfunction and thus might help to inhibit neurodegeneration [172,173] and related HD symptoms. However, LTG showed no effect on capsaicin-induced activation of the transient receptor potential vanilloid-related (TRPV1 receptors). It concentration-dependently inhibited allyl isothiocyanate (AITC)-induced TRPA1 receptors activation. Additionally, LG treatment in HEK293 cells altered TRPM7dependent inward/outward currents without alteration in cell proliferation and viability. Thus, hinting that its TRP channel-inhibiting properties may be of potential in developing novel and tolerable analgesic therapies [174]. 
Studies have shown that ISL could inhibit inflammation for parameters such as interleukin-1 $\beta$ (IL-1 $\beta$ ) and tumor necrosis factor $\alpha$ (TNF- $\alpha)$, a signaling substance secreted by macrophages during inflammation [175-178]. Although the etiology of migraine is not fully understood, there is some evidence of increased levels of IL- $1 \beta$ and TNF- $\alpha$ in migraine and chronic tension-type headache [179-181]. The implementation of WDT containing isoflavonoid compounds might be suitable for patients in the treatment of HD.

Liquiritin has been shown to inhibit progesterone metabolism by competitively inhibiting Aldo-keto reductase family 1 member $\mathrm{C} 1$, an enzyme transforming progesterone to an inactive form, thus limiting the biological effect of progesterone [182]. Considerable evidence allows a link between estrogen and progesterone and migraine [183-186]. Migraine appears more intermittently in adult women compared to men [187,188]. Menstrual-related migraine generally occurs at the time of menses in many migrainous women and exclusively with menses in some [189]. Menstrual-related migraine is often associated with other menstrual symptoms such as nausea, breast tenderness, and cramps. All symptoms appear to result from falling estrogen and progesterone levels [184]. As LG-induced inhibition of progesterone metabolism contributes to the stability of progesterone concentration levels, liquiritin might have a positive effect against migraine, nausea, and other menstrual-related symptoms.

Chen et al. have described liquiritin's antidepressant effects through fibroblast growth factor- 2 enhancement by inhibiting neuroinflammation and maintaining synaptogenesis [190]. Treatment of mice with LTG followed by polysaccharides injection, which causes acute depressive behavior, has led to a decrease in proinflammatory cytokines IL- 6 and TNF$\alpha$ in serum and hippocampus when compared with the control [168]. These antidepressant and antianxiety activities of LTG can improve patients' quality of life.

\subsection{Triterpenes}

Triterpenes are natural compounds derived biosynthetically from isoprene and consist of six isoprene units and 30 carbon atoms [191]. The vast majority of triterpenes are composed of tetra- or pentacyclic compounds [192]. Triterpenes form the basic structure of many saponins, tetrapenes, and steroids. They can be divided into three classes according to polarity: liphophilic triterpenes, highly oxidized triterpenes, and hydrophilic, glycosidic triterpenes [193].

Pachymic acid, a representative of the triterpenes, is contained in WDT as a bioactive component [2] that is found in the fungus Poriae sclerotium cocos albae (PC), a family of polyporaceae. It is claimed to have many pharmacological effects such as anti-inflammatory, antioxidant, antiemetic, diuretic, and antitumor [194-196].

Pachymic acid exerts an insulin-like, hypoglycemic activity by inducing glucose transporter type 4 gene expression and translocation to the plasma membrane in mammalian 3T3-L1 adipocytes, resulting in increased glucose uptake activity [197] as headache prevalence is greater in patients with diabetes than in non-diabetic patients [198].

Clinically, PC is mostly implemented in the treatment of hepatitis B, diabetes, cancer, metabolic syndrome, and modulation of the immune system $[199,200]$.

\subsection{Organic Acids}

Organic acids are organic compounds with a carboxylic group as a functional group. They release hydrogen ions or hydronium ions in water and have the function of donating a proton [201].

WDT contains succinate as a bioactive compound [2]. Succinate, an important metabolite, is an esterification of succinic acid and interacts in various processes in the cell [202].

The most common curable nutrition disorder is iron deficiency. Iron deficiency anemia (IDA) in adults, mostly women, in industrialized countries has a prevalence of up to $5 \%[203,204]$. The main symptoms of IDA are fatigue, vertigo, insomnia, depression, headache, brittle nails, etc. Serotonin, a neurotransmitter widely found in the central and peripheral nervous systems, plays a crucial role in migraine neurobiology [205]. An increase 
in 5-hydroxyindoleacetic acid in the urine during a migraine attack was observed by Gasparini et al. for the first time [206]. In migraine attacks, the level of serotonin is decreased in the central nervous system but increased in the peripheral nervous system [206]. As iron plays a primary role in the synthesis of serotonin, dopamine, and norepinephrine, IDA could be responsible for a reduced level of serotonin [207].

Studies have shown coherence between IDA, hemoglobin, and serum ferritin levels and headache and/or migraine occurrence, mainly in women [208,209]. There are several effective methods in the treatment of IDA. Supplement of iron protein succinylate should be considered in the therapy of HD caused by IDA [210] due to it being less adverse than iron infusion.

In a randomized, double-blind, placebo-controlled clinical study of early menopausal women, succinate-based composition treatment of mice showed restoration of the estrous cycle and an increase in the weight and calcium content of bone tissue [211]. Additionally, in a randomized, placebo-controlled clinical trial in menopausal women, a succinate-based combination therapy substantially decreased most subjectively evaluated characteristics of menopausal syndrome and enhanced blood serum levels of estradiol fourfold. It has also relieved hot flushes and headache symptoms [211].

\subsection{Polysaccharides}

Polysaccharides, possessing a broad range of biological functions, are polymeric carbohydrates consisting of more than ten monosaccharide units, which are linked together by glycoside bonds [212]. Common examples of polysaccharides are glycogen, chitin, chitosan, starch, cellulose, agarose, and pectin [213].

WDT contains Portae sclerotium Cocos algae Polysaccharides (PCPs) as a bioactive component [2]. PCPs are the most abundant substances in Poriae sclerotium cocos albae, also known as Fu Ling in Chinese, which is an edible medical fungus [200]. Traditionally, Fu Ling has been used for medicinal purposes for more than a thousand years [214]. The pharmacological actions of PCPs in Fu Ling include antibacterial, antitumor, anti-hyperglycemic, immunomodulatory, anti-inflammatory, immunostimulatory, anti-oxidative, anti-aging, anti-hepatic, anti-diabetic, and anti-hemorrhagic fever effects [200,213,215,216]. Additionally, Sun et al. showed in their study that PCPs improved hyperglycemia, hyperlipidemia, and hepatic steatosis in mice [217].

PCPs find applications in cancer therapy and many other diseases. They have been described to reduce tumor growth and improve antioxidant enzyme activity when fed daily for 7 weeks in Wistar rats [218]. As PCPs have an antitumor cell proliferation effect and inhibit tumor growth $[219,220]$, their medical administration might be beneficial to the treatment of secondary headache caused by one or more space-occupying intracranial tumors ICHD-3 7.4.1 [39].

The polysaccharide from the Poria cocos (accepted name: Poriae sclerotium cocos albae) was shown to improve hyperglycemia, hyperlipidemia, and hepatic steatosis via modulation of gut microbiota [217]. An enhancement in gut microbiota and a decline in inflammatory factors can have positive effects on improving gut and brain function. Additionally, it is suggested that probiotics might have a beneficial effect in reducing the frequency and severity of migraine attacks. It is worth mentioning that, similar to migraine, disorders of the brain involving depression and anxiety have been demonstrated to be associated with increased gut permeability [221], and probiotics boosting gut microbiota help to decrease gut permeability and prevent leaky gut syndrome [222].

In 2015, PCPs received approval from the Chinese Food and Drug Administration for treating various types of diseases such as cancer, hepatitis alone, or during chemoradiation therapy for cancer patients [213].

\subsection{Alternative Therapies}

Besides Chinese herbal medicine such as WDT, TCM also provides a broad spectrum of therapeutic modalities for HD such as acupuncture, moxibustion, cupping, tuina, exercises 
such as Tai Chi/Qi Gong, and dietary. However, the main focus of this study is the herbal medicine component of WDT.

\subsubsection{Acupuncture}

The concept of acupuncture is principally to puncture an exact acupuncture point with an acupuncture needle, with or without manipulation after insertion (i.e., tonify, sedate). The goal is to achieve harmony in the movement of energy (Qi) in the meridians and bring balance in an imbalanced region, organ, or meridian [223].

Although the exact mechanism of acupuncture is difficult to research and not yet completely understood, clinical trials have shown good evidence of acupuncture efficacy in the treatment of HD and for the prevention of migraine, TTH, or chronic HD [224]. As adverse events are mild and serious adverse events are rare, acupuncture can be considered a safe treatment [225].

\subsubsection{Topical Medicines}

The skin is the largest organ of the body. Any abnormalities in the body can manifest on the skin surface. People suffering from HD, especially migraine, tend to experience cutaneous allodynia (CA) [226]. The International Association for the Study of Pain defines allodynia as "pain due to a stimulus that does not normally provoke pain". Topical medicines in various forms such as ointments, oils, pastes, creams, lotions, foams, gels, tincture, powders, spray, and patches can be applied either to the skin or to mucous membranes. This may be used topically to treat pain or other ailments in a particular region of the body [227]. These applications may also be effective in treating CA and/or HD. St. Cyr et al. could show in their study that STOPAIN 6\% menthol gel was safe and significantly reduced headache intensity by two hours after the gel application [228]. Yuan $\mathrm{R}$ et al. revealed in their review that aromatic plant essential oils had pain-relieving effects in migraine patients due to the suppression of neurogenic inflammation and pain sensitization [229]. However, there are limitations to skin therapies in case of skin injuries and/or infection. Moreover, the local application of the skin cannot reach a distant area of pain. Therefore, systemic application of a herbal TCM formula such as WDT by ingestion can be a better choice in the case of HD [230].

\subsection{Western Medicine}

The Western medicine pharmacotherapy treatment for HD includes acute and preventive medications [42]. The gold standard of migraine and other related HD suggest the usage of triptans, non-steroidal anti-inflammatory drugs (NSAIDs), and analgesics. The prophylactic treatment contains antidepressants, anticonvulsants, $\beta$-blockers, antihypertensive medications, CGRP-Inhibitor, calcium channel antagonists, magnesium, coenzyme Q10, riboflavin, and botulinum toxin type A [231]. Analgesics and NSAIDs are the standard therapy for acute TTH [232].

If patients repeatedly consume acute headache medication too often, this can result in a medication overuse headache [233].

\section{Conclusions}

Research regarding bioactive compounds of WDT is very rare. Based on our research information, only Zhang et al. [2] and Wu et al. [30] have examined the bioactive compounds of WDT in their studies. To the best of our knowledge, no clinical trial has been completed regarding the treatment of any type of headache with WDT. Therefore, this study aimed to explore the pharmacological reaction of the API containing WDT associated with HD.

The current study gathers information on WDT compounds, which can be used as a guideline for physicians to help HD patients and to improve their QoL. The alkaloid p-synephrine can reduce primary and secondary headaches caused by rhinitis patients through its vasoconstrictive characteristics. By increasing the fat-burning rate and the expected weight loss, p-synephrine could also contribute to life quality improvement of 
obese patients and related migraine headaches. Gingerols have a promising positive effect in reducing migraine through their anti-oxidative effect and an inhibitory effect on controlling prostaglandin-biosynthesis-induced migraine through the inhibition of prostaglandin biosynthesis and in working against hypoglycemia-caused migraine by increasing glucose transport into muscle cells. Isoflavones can contribute to the control of migraine caused by increased estrogen levels as well as menstrual-associated migraine. The isoflavonoids liquiritin and liquiritingenin might exert a positive effect on Interleukin $1 \beta$-induced headache. Liquiritin shows potency to have a beneficial effect on menstrual-related migraine and nausea by inhibiting progesterone metabolism. Liquiritigenin's antidepressant and anxiolytic effects are expected to positively contribute to life quality improvement in HD patients. Hypoglycemic activity of pachymic acid exerts a positive effect against diabetes-caused secondary headache, whereas succinate-based composition helps control general menopausal and specifically headache symptoms by restoring the estrous cycle. Polysaccharide PCPs can contribute to migraine control by their anti-oxidative, anti-inflammatory, and antitumor effects and as probiotics enhancing gut microbiota composition.

These findings suggest that WDT, as a combination of these APIs, might be beneficial in treating several diseases, particularly for patients with phlegm turbidity HD. Currently, there is no sufficient clinical research investigating the pharmacological effects and the mechanisms of action of WDT. Consequently, more clinical trials are needed to better understand the treatment of HD with WDT.

High-quality clinical research over a long period with a larger patient group should be carried out to evaluate the therapeutic effectiveness of WDT in HD to investigate if WDT could be a suitable prescription for people with HD, especially migraine and TTH.

Our study lacks all the other clinical trials completed for various diseases other than HD. Moreover, the effect sizes of the API in WDT were not examined to investigate the etiopathogenetic mechanism of WDT. Nevertheless, our article contains HD as a primary and secondary disorder to other pathologies. Thus, it brings a broader spectrum of herbal use for therapeutic and prophylactic treatment for all types of HD.

This manuscript is significant because it holds collective evidence to address the multipotency of WDT and their bioactive components in detail. In conclusion, this study raises the importance of a conclusive clinical trial of WDT with large samples for patients treating migraine and TTH.

Author Contributions: Conceptualization: S.K.P., S.L. and F.A.; methodology: S.K.P., H.S., A.R.G. and Y.L.; writing - original draft preparation: S.K.P.; writing-review and editing S.K.P., H.S., Y.L., A.R.G., F.A. and S.L.; supervision: Y.L. All authors have read and agreed to the published version of the manuscript.

Funding: This research received no external funding.

Data Availability Statement: All data generated or analyzed during this study are included in this published article.

Acknowledgments: This review was supported by Zurzach Rehabilitation Foundation SPA and the Swiss Traditional Chinese Medicine Academy (STA). The supporting sources had no role in designing this study, in writing the manuscript, or in deciding to submit this manuscript.

Conflicts of Interest: The authors declare no conflict of interest.

\section{References}

1. NATCM. 2018. Available online: http:// kjs.satcm.gov.cn/zhengcewenjian/2018-04-16/7107.html (accessed on 14 September 2020).

2. Zhang, B.; Qi, D.; Deng, X.; Ma, Z.; Wu, Y.; Xue, Z.; Kebebe, D.; Lu, P.; Pi, J.; Guo, P. Quantification of nineteen bioactive components in the ancient classical Chinese medicine formula of Wen-Dan decoction and its commercial preparations by UHPLC-QQQ-MS/MS. Molecules 2019, 24, 2031. [CrossRef] [PubMed]

3. Su, T.; Tan, Y.; Tsui, M.-S.; Yi, H.; Fu, X.-Q.; Li, T.; Chan, C.L.; Guo, H.; Li, Y.-X.; Zhu, P.-L.; et al. Metabolomics reveals the mechanisms for the cardiotoxicity of Pinelliae Rhizoma and the toxicity-reducing effect of processing. Sci. Rep. 2016, 6, 34692. [CrossRef] [PubMed] 
4. Seok, J.K.; Kwak, J.Y.; Seo, H.H.; Suh, H.J.; Boo, Y.C. Effects of Bambusae caulis in Taeniam extract on the UVB-induced cell death, oxidative stress and matrix metalloproteinase 1 expression in keratinocytes. J. Soc. Cosmet. Sci. Korea 2015, 41, 9-20.

5. Kim, A.; Im, M.; Yim, N.-H.; Jung, Y.P.; Ma, J.Y. Aqueous extract of Bambusae Caulis in Taeniam inhibits PMA-induced tumor cell invasion and pulmonary metastasis: Suppression of NF- $\mathrm{kB}$ activation through ROS signaling. PLoS ONE 2013, 8, e78061. [CrossRef]

6. Fang, Y.-S.; Shan, D.-M.; Liu, J.-W.; Xu, W.; Li, C.-L.; Wu, H.-Z.; Ji, G. Effect of constituents from Fructus Aurantii Immaturus and Radix Paeoniae Alba on gastrointestinal movement. Planta Med. 2009, 75, 24-31. [CrossRef]

7. Tan, W.; Li, Y.; Wang, Y.; Zhang, Z.; Wang, T.; Zhou, Q.; Wang, X. Anti-coagulative and gastrointestinal motility regulative activities of Fructus Aurantii Immaturus and its effective fractions. Biomed. Pharmacother. 2017, 90, 244-252. [CrossRef]

8. Shi, Q.; Liu, Z.; Yang, Y.; Geng, P.; Zhu, Y.; Zhang, Q.; Bai, F.; Bai, G. Identification of anti-asthmatic compounds in Pericarpium citri reticulatae and evaluation of their synergistic effects. Acta Pharmacol. Sin. 2009, 30, 567-575. [CrossRef]

9. Luo, M.; Luo, H.; Hu, P.; Yang, Y.; Wu, B.; Zheng, G. Evaluation of chemical components in Citri Reticulatae Pericarpium of different cultivars collected from different regions by GC-MS and HPLC. Food Sci. Nutr. 2018, 6, 400-416. [CrossRef]

10. Wang, F.; Chen, L.; Li, F.; Liu, S.; Chen, H.; Liu, Y. The increase of flavonoids in Pericarpium Citri Reticulatae (PCR) induced by fungi promotes the increase of antioxidant activity. Evid.-Based Complement. Altern. Med. 2018, 2018, 2506037. [CrossRef]

11. Yu, J.; Guo, J.; Zhu, K.Y.; Tao, W.; Chen, Y.; Liu, P.; Hua, Y.; Tang, Y.; Duan, J.-A. How impaired efficacy happened between Gancao and Yuanhua: Compounds, targets and pathways. Sci. Rep. 2017, 7, 3828. [CrossRef]

12. Li, N.; Zhou, T.; Wu, F.; Wang, R.; Zhao, Q.; Zhang, J.-Q.; Yang, B.-C.; Ma, B.-L. Pharmacokinetic mechanisms underlying the detoxification effect of Glycyrrhizae Radix et Rhizoma (Gancao): Drug metabolizing enzymes, transporters, and beyond. Expert Opin. Drug Metab. Toxicol. 2019, 15, 167-177. [CrossRef]

13. Ríos, J.-L. Chemical constituents and pharmacological properties of Poria cocos. Planta Med. 2011, 77, 681-691. [CrossRef]

14. Wang, D.; Huang, C.; Zhao, Y.; Wang, L.; Yang, Y.; Wang, A.; Zhang, Y.; Hu, G.; Jia, J. Comparative studies on polysaccharides, triterpenoids, and essential oil from fermented mycelia and cultivated sclerotium of a medicinal and edible mushroom, Poria Cocos. Molecules 2020, 25, 1269. [CrossRef]

15. Chrubasik, S.; Pittler, M.H.; Roufogalis, B.D. Zingiberis rhizoma: A comprehensive review on the ginger effect and efficacy profiles. Phytomedicine 2005, 12, 684-701. [CrossRef]

16. Dong, Y.; Yao, K.-W.; Wang, J. Pharmacological effects and clinical applications of Zingiber officinale and its processed products. China J. Chin. Mater. Med. 2018, 43, 2020-2024.

17. Lam, C.T.W.; Chan, P.H.; Lee, P.S.C.; Lau, K.M.; Kong, A.Y.Y.; Gong, A.G.W.; Xu, M.L.; Lam, K.Y.C.; Dong, T.T.X.; Lin, H. Chemical and biological assessment of Jujube (Ziziphus jujuba)-containing herbal decoctions: Induction of erythropoietin expression in cultures. J. Chromatogr. B 2016, 1026, 254-262. [CrossRef]

18. Chen, J.; Liu, X.; Li, Z.; Qi, A.; Yao, P.; Zhou, Z.; Dong, T.T.X.; Tsim, K.W.K. A review of dietary Ziziphus jujuba fruit (Jujube): Developing health food supplements for brain protection. Evid.-Based Complement. Altern. Med. 2017, 2017, 3019568. [CrossRef]

19. Deng, H.; Xu, J. Wendan decoction (Traditional Chinese medicine) for schizophrenia. Cochrane Database Syst. Rev. 2017. [CrossRef]

20. Chen, J.K.; Chen, T.T. Chinesische Pharmakologie II. Rezepturen und Therapiestrategien; John, K., Ed.; Verlag Systemische Medizin: Bad Kötzting, Germany, 2009.

21. Song, Y.; Li, F.; Liu, Y.; Ma, J.; Mao, M.; Wu, F. Effects of Wen Dan Tang on insomnia-related anxiety and levels of the brain-gut peptide Ghrelin. Neural Regen. Res. 2014, 9, 205. [CrossRef]

22. Wang, Y.-N.; Hou, Y.-Y.; Sun, M.-Z.; Zhang, C.-Y.; Bai, G.; Zhao, X. Behavioural screening of zebrafish using neuroactive traditional Chinese medicine prescriptions and biological targets. Sci. Rep. 2014, 4, 5311. [CrossRef]

23. Chen, M.; Yang, F.; Kang, J.; Gan, H.; Lai, X.; Gao, Y. Metabolomic investigation into molecular mechanisms of a clinical herb prescription against metabolic syndrome by a systematic approach. RSC Adv. 2017, 7, 55389-55399. [CrossRef]

24. Singh, A.; Zhao, K. Treatment of insomnia with traditional chinese herbal medicine. Int. Rev. Neurobiol. 2017, 135, 97-115. [CrossRef]

25. Huang, Y.-M.; Xu, J.-H.; Ling, W.; Li, Y.; Zhang, X.-X.; Dai, Z.-K.; Sui, Y.; Zhao, H.-L. Efficacy of the wen dan decoction, a Chinese herbal formula, for metabolic syndrome. Altern. Ther. Health Med. 2015, 21, 54-67.

26. Ling, W.; Huang, Y.; Xu, J.-H.; Li, Y.; Huang, Y.-M.; Ling, H.-B.; Sui, Y.; Zhao, H.-L. Consistent Efficacy of Wendan Decoction for the Treatment of Digestive Reflux Disorders. Am. J. Chin. Med. 2015, 43, 893-913. [CrossRef]

27. Yan, X.; Wang, Y.; Li, X.; Li, Z.; Zhang, Y.; Cai, X.; Wang, D. Wendan decoction for primary insomnia: Protocol for a systematic review and meta-analysis. Medicine 2017, 96, e8906. [CrossRef]

28. Lan, T.-H.; Zhang, L.-L.; Wang, Y.-H.; Wu, H.-L.; Xu, D.-P. Systems Pharmacology Dissection of Traditional Chinese Medicine Wen-Dan Decoction for Treatment of Cardiovascular Diseases. Evid.-Based Complement. Altern. Med. 2018, 2018, 5170854. [CrossRef]

29. Lee, S.-E.; Lim, C.; Lee, M.; Kim, C.-H.; Kim, H.; Lee, B.; Cho, S. Assessing Neuroprotective Effects of Glycyrrhizae Radix et Rhizoma Extract Using a Transient Middle Cerebral Artery Occlusion Mouse Model. J. Vis. Exp. 2018, 142, e58454. [CrossRef]

30. Wu, F.; Song, Y.; Li, F.; He, X.; Ma, J.; Feng, T.; Guan, B.; Wang, L.; Li, S.; Liu, X.; et al. Wen-dan decoction improves negative emotions in sleep-deprived rats by regulating orexin-a and leptin expression. Evid.-Based Complement. Altern. Med. 2014, 2014, 872547. [CrossRef]

31. Feng, W.; Ye, X.; Lv, H.; Hou, C.; Chen, Y. Wendan decoction for dyslipidemia: Protocol for a systematic review and meta-analysis Medicine 2019, 98, e14159. [CrossRef]

32. Xu, J.-H.; Huang, Y.-M.; Ling, W.; Li, Y.; Wang, M.; Chen, X.-Y.; Sui, Y.; Zhao, H.-L. Wen Dan Decoction for hemorrhagic stroke and ischemic stroke. Complement. Ther. Med. 2015, 23, 298-308. [CrossRef] 
33. Min, L.; Liang, Y. Sun Simiao, super physician of the Tang Dynasty. J. Tradit. Chin. Med. Sci. 2015, 2, 69-70. [CrossRef]

34. Unschuld, P.U. Der Chinesische “Arzneikönig" Sun Simiao Geschichte-Legende-Ikonographie Zur Plausibilität Naturkundlicher und Übernatürlicher Erklärungsmodelle. Monum. Serica 1994, 42, 217-257. [CrossRef]

35. Shen, X.; Zheng, W.; Ma, M.; Zhang, Z. The classification method of syndromes in the Bei ji qian jin yao fang (essential recipes for emergent use worth a thousand gold). Zhonghua Yi Shi Za Zhi Beijing China 2014, 44, 77-80.

36. Dr. Noyer. AG/TCM., Dr Noyer. Available online: https://www.drnoyertcm.com/de/tcm-arzneimittel/dr-noyer-tcm-tropfen (accessed on 12 August 2020).

37. Stovner, L.J.; Nichols, E.; Steiner, T.J.; Abd-Allah, F.; Abdelalim, A.; Al-Raddadi, R.M. Global, regional, and national burden of migraine and tension-type headache, 1990-2016: A systematic analysis for the Global Burden of Disease Study 2016. Lancet Neurol. 2018, 17, 954-976. [CrossRef]

38. Sokolovic, E.; Riederer, F.; Szucs, T.; Agosti, R.; Sándor, P.S. Self-reported headache among the employees of a Swiss university hospital: Prevalence, disability, current treatment, and economic impact. J. Headache Pain 2013, 26, 14-29. [CrossRef]

39. Arnold, M. Headache classification committee of the international headache society (ihs) the international classification of headache disorders. Cephalalgia 2018, 38, 1-211.

40. Pradhan, S.K. Komplementärmedizinische Behandlung von Kopfschmerz am Beispiel der Akupunktur. Schweiz. Z. Für Psychiatr. Neurol. 2020, 3, 42-43.

41. Wang, Q.; Yang, J.; Gao, S. The Teaching of Acupuncture and Moxibustion. In Tou Teng (Headache); Zhong Guo Zho Yi Yao Chu Ban She: Beijing, China, 2007.

42. Rizzoli, P.; Mullally, W.J. Headache. Am. J. Med. 2018, 131, 17-24. [CrossRef]

43. Huang, H.; Jing, F.; Shi, Y.; Shou, C. Jing Fang User Manual, 2nd ed.; Zhong Guo Zho Yi Yao Chu Ban She: Beijing, China, 2015; pp. 116-117.

44. Li, J.; Wang, Y.; He, D.; Fang, J.X. Prescriptions of Chinese Materia Medica; Zhong Guo Zho Yi Yao Chu Ban She: Beijing, China, 2022

45. Giovanni, M. The Foundations of Chinese Medicine: A Comprehensive Text for Acupuncturists and Herbalists; Churchill Livingstone: Edinburgh, UK, 1989.

46. Alam, M.A.; Subhan, N.; Rahman, M.M.; Uddin, S.J.; Reza, H.M.; Sarker, S.D. Effect of citrus flavonoids, naringin and naringenin, on metabolic syndrome and their mechanisms of action. Adv. Nutr. 2014, 5, 404-417. [CrossRef]

47. Cui, G.; Zhang, W.; Wang, Q.; Zhang, A.; Mu, H.; Bai, H. Extraction optimization, characterization and immunity activity of polysaccharides from Fructus Jujubae. Carbohydr. Polym. 2014, 111, 245-255. [CrossRef]

48. Wu, Z.; Zhang, S.; Li, P.; Lu, X.; Wang, J.; Zhao, L. Effect of aurantii fructus immaturus flavonoid on the contraction of isolated gastric smooth muscle strips in rats. Evid.-Based Complement. Altern. Med. 2016, 2016, 5616905. [CrossRef]

49. Martins, L.B.; Rodrigues, A.M.D.S.; Rodrigues, D.F.; Dos Santos, L.C.; Teixeira, A.L.; Ferreira, A.V.M. Double-blind placebocontrolled randomized clinical trial of ginger (Zingiber officinale Rosc.) addition in migraine acute treatment. Cephalalgia 2019, 39, 68-76. [CrossRef]

50. Lin, S.; Nie, B.; Song, K.; Ye, R.; Yuan, Z. Pinelliae Rhizoma Praeparatum cum Alumine extract: Sedative and hypnotic effects in mice and component compounds. BioMed Res. Int. 2019, 2019, 6198067. [CrossRef]

51. Liu, X.; Wang, X.; Xu, X.; Zhang, X. Purification, antitumor and anti-inflammation activities of an alkali-soluble and carboxymethyl polysaccharide CMP33 from Poria cocos. Int. J. Biol. Macromol. 2019, 127, 39-47. [CrossRef]

52. Park, S.H.; Kim, J.-C. In vitro anti-inflammatory efficacy of Bambusae Caulis in Taeniam extract loaded in monoolein cubosomes. J. Ind. Eng. Chem. 2019, 77, 189-197. [CrossRef]

53. A.C.D./ChemSketch. ChemSketch; Advanced Chemistry Development, Inc.: Toronto, ON, Canada, 2022.

54. Hussain, G.; Rasul, A.; Anwar, H.; Aziz, N.; Razzaq, A.; Wei, W.; Ali, M.; Li, J.; Li, X. Role of Plant Derived Alkaloids and Their Mechanism in Neurodegenerative Disorders. Int. J. Biol. Sci. 2018, 14, 341-357. [CrossRef]

55. Kukula-Koch, W.A.; Widelski, J. Alkaloids. In Pharmacognosy; Badal, S., Delgoda, R., Eds.; Academic Press: Cambridge, MA, USA, 2017; pp. 163-198.

56. Stohs, S.J.; Ratamess, N.A. Effects of p-synephrine in combination with caffeine: Review. Nutr. Diet. Suppl. 2017, 9, 87-96. [CrossRef]

57. Stohs, S.J.; Preuss, H.G.; Shara, M. The safety of Citrus aurantium (bitter orange) and its primary protoalkaloid p-synephrine. Phytother. Res. 2011, 25, 1421-1428. [CrossRef]

58. Shan, Y. Functional Components of Citrus Peel. In Comprehensive Utilization of Citrus By-Products; Shan, Y., Ed.; Academic Press: Cambridge, MA, USA, 2016; pp. 1-13.

59. Stohs, S.J.; Preuss, H.G.; Shara, M. A Review of the Receptor-Binding Properties of p-Synephrine as Related to Its Pharmacological Effects. Oxidative Med. Cell. Longev. 2011, 2011, 482973. [CrossRef]

60. Chiarugi, A.; Camaioni, A. Update on the pathophysiology and treatment of rhinogenic headache: Focus on the ibuprofen/pseudoephedrine combination. Acta Otorhinolaryngol. Ital. 2019, 39, 22. [CrossRef]

61. Berry, M.D. Mammalian central nervous system trace amines. Pharmacologic amphetamines, physiologic neuromodulators. J. Neurochem. 2004, 90, 257-271. [CrossRef]

62. D'Andrea, G.; Perini, F.; Terrazzino, S.; Nordera, G.P. Contributions of biochemistry to the pathogenesis of primary headaches. Neurological Sciences. Neurol. Sci. 2004, 25, 89-92. [CrossRef] 
63. D'andrea, G.; Nordera, G.P.; Perini, F.; Allais, G.; Granella, F. Biochemistry of neuromodulation in primary headaches: Focus on anomalies of tyrosine metabolism. Neurol. Sci. 2007, 28, 94-96. [CrossRef]

64. Farooqui, T. Trace Amines and Their Potential Role in Primary Headaches: An Overview. In Trace Amines and Neurological Disorders; Farooqui, T., Farooqui, A.A., Eds.; Academic Press: Cambridge, MA, USA, 2016; pp. 349-366.

65. Lafontan, M.; Berlan, M. Fat cell adrenergic receptors and the control of white and brown fat cell function. J. Lipid Res. 1993, 34, 1057-1091. [CrossRef]

66. Guo, S.; Olesen, J.; Ashina, M. Phosphodiesterase 3 inhibitor cilostazol induces migraine-like attacks via cyclic AMP increase Brain 2014, 137, 2951-2959. [CrossRef]

67. Madsen, L.; Kristiansen, $\mathrm{K}$. The importance of dietary modulation of cAMP and insulin signaling in adipose tissue and the development of obesity. Ann. N. Y. Acad. Sci. 2010, 1190,1-14. [CrossRef]

68. Gutiérrez-Hellín, J.; Del Coso, J. Acute p-synephrine ingestion increases fat oxidation rate during exercise. Br. J. Clin. Pharmacol. 2016, 82, 362-368. [CrossRef]

69. Mika, A.; Macaluso, F.; Barone, R.; Di Felice, V.; Sledzinski, T. Effect of Exercise on Fatty Acid Metabolism and Adipokine Secretion in Adipose Tissue. Front. Physiol. 2019, 10, 26. [CrossRef]

70. Stohs, S.J.; Preuss, H.G.; Keith, S.C.; Keith, P.L.; Miller, H.; Kaats, G.R. Effects of p-synephrine alone and in combination with selected bioflavonoids on resting metabolism, blood pressure, heart rate and self-reported mood changes. Int. J. Med. Sci. 2011, 8 , 295-301. [CrossRef]

71. Kaats, G.R.; Miller, H.; Preuss, H.G.; Stohs, S.J. A 60 day double-blind, placebo-controlled safety study involving Citrus aurantium (bitter orange) extract. Food Chem. Toxicol. 2013, 55, 358-362. [CrossRef]

72. Stohs, S.J.; Badmaev, V. A review of natural stimulant and non-stimulant thermogenic agents. Phytother. Res. 2016, 30, 732-740. [CrossRef] [PubMed]

73. Shara, M.; Stohs, S.J.; Mukattash, T.L. Cardiovascular safety of oral p-synephrine (bitter orange) in healthy subjects: A randomized placebo-controlled cross-over clinical trial. Phytother. Res. 2016, 30, 842-847. [CrossRef] [PubMed]

74. Arbo, M.D.; Larentis, E.R.; Linck, V.M.; Aboy, A.L.; Pimentel, A.L.; Henriques, A.T.; Dallegrave, E.; Garcia, S.C.; Leal, M.B.; Limberger, R.P. Concentrations of p-synephrine in fruits and leaves of Citrus species (Rutaceae) and the acute toxicity testing of Citrus aurantium extract and p-synephrine. Food and chemical toxicology. Food Chem. Toxicol. 2008, 46, 2770-2775. [CrossRef] [PubMed]

75. Arbo, M.D.; Franco, M.T.; Larentis, E.R.; Garcia, S.C.; Sebben, V.C.; Leal, M.B.; Dallegrave, E.; Limberger, R.P. Screening for in vivo (anti) estrogenic activity of ephedrine and p-synephrine and their natural sources Ephedra sinica Stapf.(Ephedraceae) and Citrus aurantium L.(Rutaceae) in rats. Arch. Toxicol. 2009, 83, 95-99. [CrossRef]

76. Arbo, M.D.; Schmitt, G.C.; Limberger, M.F.; Charão, M.F.; Moro, Â.M.; Ribeiro, G.L.; Dallegrave, E.; Garcia, S.C.; Leal, M.B.; Limberger, R.P. Subchronic toxicity of Citrus aurantium L.(Rutaceae) extract and p-synephrine in mice. Regul. Toxicol. Pharmacol. 2009, 54, 114-117. [CrossRef]

77. Rossato, L.G.; Costa, V.M.; De Pinho, P.G.; Carvalho, F.; de Lourdes Bastos, M.; Remião, F. Structural isomerization of synephrine influences its uptake and ensuing glutathione depletion in rat-isolated cardiomyocytes. Arch. Toxicol. 2011, 85, 929-939. [CrossRef]

78. Bond, D.S.; Thomas, J.G.; Lipton, R.B.; Roth, J.; Pavlovic, J.M.; Rathier, L. Behavioral weight loss intervention for migraine: A randomized controlled trial. Obesity 2018, 26, 81-87. [CrossRef]

79. Kaats, G.R.; Leckie, R.B.; Mrvichin, N.; Stohs, S.J. Increased eating control and energy levels associated with consumption of bitter orange (p-synephrine) extract: A randomized placebo-controlled study. Nutr. Diet. Suppl. 2017, 9, 29. [CrossRef]

80. Minen, M.T.; De Dhaem, O.B.; Van Diest, A.K.; Powers, S.; Schwedt, T.J.; Lipton, R.; Silbersweig, D. Migraine and its psychiatric comorbidities. J. Neurol. Neurosurg. Psychiatry 2016, 87, 741-749. [CrossRef]

81. Dindo, L.N.; Recober, A.; Haddad, R.; Calarge, C.A. Comorbidity of migraine, major depressive disorder, and generalized anxiety disorder in adolescents and young adultsAdults. Int. J. Behav. Med. 2017, 24, 528-534. [CrossRef]

82. Amoozegar, F. Depression comorbidity in migraine. Int. Rev. Psychiatry 2017, 29, 504-515. [CrossRef]

83. Hung, C.I.; Liu, C.Y.; Yang, C.H.; Wang, S.J. Migraine and greater pain symptoms at 10-year follow-up among patients with major depressive disorder. J. Headache Pain 2018, 19, 56. [CrossRef]

84. Kim, K.W.; Kim, H.D.; Jung, J.S.; Woo, R.S.; Kim, H.S.; Suh, H.W.; Kim, Y.H.; Song, D.K. Characterization of antidepressant-like effects of p-synephrine stereoisomers. Naunyn-Schmiedeberg's Arch. Pharmacol. 2001, 364, 21-26. [CrossRef]

85. Pereira, M.A.O.; Pereira, A., Jr. On the effect of aromatherapy with citrus fragrance in the therapy of major depressive disorder. J. Psychol. Psychother. 2014, 5, 1-3. [CrossRef]

86. Carvalho-Freitas, M.; Costa, M. Anxiolytic and sedative effects of extracts and essential oil from Citrus aurantium L. Biol. Pharm. Bull. 2002, 25, 1629-1633. [CrossRef]

87. De Moraes Pultrini, A.; Galindo, L.A.; Costa, M. Effects of the essential oil from Citrus aurantium L. in experimental anxiety models in mice. Life Sci. 2006, 78, 1720-1725. [CrossRef]

88. Leite, M.P.; Fassin, J., Jr.; Baziloni, E.M.; Almeida, R.N.; Mattei, R.; Leite, J.R. Behavioral effects of essential oil of Citrus aurantium L. inhalation in rats. Rev. Bras. Farmacogn. 2008, 18, 661-666. [CrossRef]

89. Mannucci, C.; Calapai, F.; Cardia, L.; Inferrera, G.; D’Arena, G.; Di Pietro, M.; Navarra, M.; Gangemi, S.; Spagnolo, E.V.; Calapai, G. Clinical Pharmacology of Citrus aurantium and Citrus sinensis for the Treatment of Anxiety. Evid.-Based Complement. Altern. Med. Ecam 2018, 2018, 3624094. [CrossRef] 
90. Pimenta, F.C.F.; Alves, M.F.; Pimenta, M.B.F.; Melo, S.A.L.; Almeida, A.A.F.D.; Leite, J.R.; Almeida, R.N.D. Anxiolytic effect of Citrus aurantium L. on patients with chronic myeloid leukemia. Phytother. Res. 2016, 30, 613-617. [CrossRef]

91. National Center for Biotechnology Information. PubChem Compound Summary for CID 996, Phenol. Available online: https:/ / pubchem.ncbi.nlm.nih.gov/compound/Phenol (accessed on 20 February 2021).

92. Fitzpatrick, L.R.; Woldemariam, T. Small-molecule drugs for the treatment of inflammatory bowel disease. In Comprehensive Medicinal Chemistry III; Chackalamannil, S., Rotella, D., Ward, S.E., Eds.; Elsevier: Amsterdam, The Netherlands, 2017; pp. $495-510$.

93. Semwal, R.B.; Semwal, D.K.; Combrinck, S.; Viljoen, A.M. Gingerols and shogaols: Important nutraceutical principles from ginger. Phytochemistry 2015, 117, 554-568. [CrossRef]

94. Dugasani, S.; Pichika, M.R.; Nadarajah, V.D.; Balijepalli, M.K.; Tandra, S.; Korlakunta, J.N. Comparative antioxidant and antiinflammatory effects of [6]-gingerol,[8]-gingerol,[10]-gingerol and [6]-shogaol. J. Ethnopharmacol. 2010, 127, 515-520. [CrossRef]

95. National Center for Biotechnology Information. PubChem Compound Summary for CID 3473, [6]-Gingerol. Available online: https:/ / pubchem.ncbi.nlm.nih.gov/ compound/6_-Gingerol (accessed on 20 February 2021).

96. Bode, A.M.; Dong, Z. The amazing and mighty ginger. In Herbal Medicine: Biomolecular and Clinical Aspects; CRC Press: Boca Raton, FL, USA, 2011; Volume 2.

97. Borkum, J.M. The migraine attack as a homeostatic, neuroprotective response to brain oxidative stress: Preliminary evidence for a theory. Headache J. Head Face Pain 2018, 58, 118-135. [CrossRef]

98. Tripathi, G.M.; Kalita, J.; Misra, U.K. A study of oxidative stress in migraine A study of oxidative stress in migraine with special reference to prophylactic therapy. Int. J. Neurosci. 2018, 128, 318-324. [CrossRef]

99. Togha, M.; Razeghi Jahromi, S.; Ghorbani, Z.; Ghaemi, A.; Rafiee, P. An investigation of oxidant/antioxidant balance in patients with migraine: A case-control study. BMC Neurol. 2019, 19, 323. [CrossRef]

100. Aeschbach, R.; Löliger, J.; Scott, B.C.; Murcia, A.; Butler, J.; Halliwell, B.; Aruoma, O.I. Antioxidant actions of thymol, carvacrol, 6-gingerol, zingerone and hydroxytyrosol. Food Chem. Toxicol. 1994, 32, 31-36. [CrossRef]

101. Ippoushi, K.; Ito, H.; Horie, H.; Azuma, K. Mechanism of Inhibition of Peroxynitrite-Mechanism of inhibition of peroxynitriteinduced oxidation and nitration by [6]-gingerol. Planta Med. 2005, 71, 563-566. [CrossRef]

102. Ahmad, B.; Rehman, M.U.; Amin, I.; Arif, A.; Rasool, S.; Bhat, S.A.; Afzal, I.; Hussain, I.; Bilal, S. A review on pharmacological properties of zingerone (4-(4-Hydroxy-3-methoxyphenyl)-2-butanone). Sci. World J. 2015, 2015, 816364. [CrossRef]

103. Gunathilake, K.D.P.P.; Rupasinghe, H.V. Recent perspectives on the medicinal potential of ginger. Bot. Targets Ther. 2015, 5, 55-63. [CrossRef]

104. Tanveer, S.; Aamir, S.; Masood, S.B.; Muhammad, S. Radical scavenging linked antioxidant comparison and quantification of conventional and supercritical fluid ginger extracts. J. Nutr. Food Sci. 2016, 6. [CrossRef]

105. Gholamian-Dehkordi, N.; Luther, T.; Asadi-Samani, M.; Mahmoudian-Sani, M.R. An overview on natural antioxidants for oxidative stress reduction in cancers; a systematic review. Immunopathol. Persa 2017, 3, e12. [CrossRef]

106. Mohd Sahardi, N.F.N.; Makpol, S. Ginger (Zingiber officinale Roscoe) in the prevention of ageing and degenerative diseases: Review of current evidence. Evid.-Based Complement. Altern. Med. 2019, 2019, 5054395. [CrossRef] [PubMed]

107. Maghbooli, M.; Golipour, F.; Moghimi Esfandabadi, A.; Yousefi, M. Comparison between the efficacy of ginger and sumatriptan in the ablative treatment of the common migraine. Phytother. Res. 2014, 28, 412-415. [CrossRef] [PubMed]

108. Antonova, M.; Wienecke, T.; Olesen, J.; Ashina, M. Prostaglandin E2 induces immediate migraine-like attack in migraine patients without aura. Cephalalgia 2012, 32, 822-833. [CrossRef] [PubMed]

109. Antonova, M.; Wienecke, T.; Olesen, J.; Ashina, M. Prostaglandins in migraine: Update. Curr. Opin. Neurol. 2013, 26, 269-275. [CrossRef]

110. Kiuchi, F.; Iwakami, S.; Shibuya, M.; Hanaoka, F.; Sankawa, U. Inhibition of prostaglandin and leukotriene biosynthesis by gingerols and diarylheptanoids. Chem. Pharm. Bull. 1992, 40, 387-391. [CrossRef]

111. Tripathi, S.; Maier, K.G.; Bruch, D.; Kittur, D.S. Effect of 6-gingerol on pro-inflammatory cytokine production and costimulatory molecule expression in murine peritoneal macrophages. J. Surg. Res. 2007, 138, 209-213. [CrossRef]

112. Shivashankara, R.; Haniadka, R.; Fayad, P.L.; Palatty, R.; Arora, M.S.; Baliga, A. (Eds.) Chapter 42-Hepatoprotective Effects of Zingiber officinale Roscoe (Ginger): A Review; Academic Press: Cambridge, MA, USA, 2013.

113. Mao, Q.Q.; Xu, X.Y.; Cao, S.Y.; Gan, R.Y.; Corke, H.; Li, H.B. Bioactive compounds and bioactivities of ginger (Zingiber officinale Roscoe). Foods 2019, 8, 185. [CrossRef]

114. Duke, C.C.; Roufogalis, B.D.; Heather, A.K.; Li, X.H.; McGrath, K.C.; Tran, V.H.; Li, Y.M. Attenuation of proinflammatory responses by S-[6]-gingerol via inhibition of ROS/NF-kappa B/COX2 activation in HuH7 cells. Evid.-Based Complement. Altern. Med. 2013, 2013, 146142. [CrossRef]

115. Young, H.Y.; Luo, Y.L.; Cheng, H.Y.; Hsieh, W.C.; Liao, J.C.; Peng, W.H. Analgesic and anti-inflammatory activities of 6-gingerol. J. Ethnopharmacol. 2005, 96, 207-210. [CrossRef]

116. Pan, M.H.; Hsieh, M.C.; Hsu, P.C.; Ho, S.Y.; Lai, C.S.; Wu, H.; Sang, S.; Ho, C.T. 6-Shogaol suppressed lipopolysaccharide-induced up-expression of iNOS and COX-2 in murine macrophages. Mol. Nutr. Food Res. 2008, 52, 1467-1477. [CrossRef]

117. Sedighi, S.; Nasiri, B.; Alipoor, R.; Moradi-kor, N. Modulation of 6-gingerolin Antidepressant-like Effects: An Investigation of Serotonergic System in Mice Model. GMJ Med. 2017, 1, 21-26. [CrossRef] 
118. Więdłocha, M.; Marcinowicz, P.; Krupa, R.; Janoska-Jaździk, M.; Janus, M.; Dębowska, W.; Mosiołek, A.; Waszkiewicz, N.; Szulc, A. Effect of antidepressant treatment on peripheral inflammation markers-A meta-analysis. Prog. Neuro-Psychopharmacol. Biol. Psychiatry 2018, 80, 217-226. [CrossRef]

119. Li, Y.; Tran, V.H.; Duke, C.C.; Roufogalis, B.D. Gingerols of Zingiber officinale enhance glucose uptake by increasing cell surface GLUT4 in cultured L6 myotubes. Planta Med. 2012, 78, 1549-1555. [CrossRef]

120. Habtemariam, S. The chemical and pharmacological basis of ginger (Zingiber officinale Roscoe) as potential therapy for diabetes and metabolic syndrome. In Medicinal Foods as Potential Therapies for Type-2 Diabetes and Associated Diseases; Habtemariam, S., Ed.; Academic Press: Cambridge, MA, USA, 2019; pp. 639-687.

121. Ríos, J.L.; Andújar, I.; Schinella, G.R.; Francini, F. Modulation of diabetes by natural products and medicinal plants via incretins. Planta Med. 2019, 85, 825-839. [CrossRef]

122. Vargas, E.; Joy, N.V.; Carrillo Sepulveda, M.A. (Eds.) Biochemistry, Insulin Metabolic Effects; StatPearls Publishing: Treasure Island, FL, USA, 2021.

123. Subramanian, S.; Baidal, D. (Eds.) The Management of Type 1 Diabetes; MDText.com, Inc.: South Dartmouth, MA, USA, 2021.

124. Tokarz, V.L.; MacDonald, P.E.; Klip, A. The cell biology of systemic insulin function. J. Cell Biol. 2018, 217, 2273-2289. [CrossRef]

125. Bansal, M.; Singh, N.; Pal, S.; Dev, I.; Ansari, K.M. Chemopreventive role of dietary phytochemicals in colorectal cancer. Adv. Mol. Toxicol. 2018, 12, 69-121. [CrossRef]

126. Reed, M.L.; Fanning, K.M.; Serrano, D.; Buse, D.C.; Lipton, R.B. Persistent frequent nausea is associated with progression to chronic migraine: AMPP study results. Headache J. Head Face Pain 2015, 55, 76-87. [CrossRef]

127. Gajria, K.; Lee, L.K.; Flores, N.M.; Aycardi, E.; Gandhi, S.K. Humanistic and economic burden of nausea and vomiting among migraine sufferers. J. Pain Res. 2017, 10, 689-698. [CrossRef]

128. Pertz, H.H.; Lehmann, J.; Roth-Ehrang, R.; Elz, S. Effects of ginger constituents in the gastrointestinal tract: Role of cholinergic M3 and serotonergic 5-HT3 and 5-HT4 receptors. Planta Med. 2011, 77, 973-978. [CrossRef]

129. Walstab, J.; Krüger, D.; Stark, T.; Hofmann, T.; Demir, I.E.; Ceyhan, G.O.; Feistel, B.; Schemann, M.; Niesler, B. Ginger and its pungent constituents non-competitively inhibit activation of human recombinant and native 5-HT3 receptors of enteric neurons Neurogastroenterol. Motil. 2013, 25, 439-e302. [CrossRef]

130. Jin, Z.; Lee, G.; Kim, S.; Park, C.S.; Park, Y.S.; Jin, Y.H. Ginger and its pungent constituents non-competitively inhibit serotonin currents on visceral afferent neurons. Korean J. Physiol. Pharmacol. 2014, 18, 149-153. [CrossRef] [PubMed]

131. Ullah, I.; Subhan, F.; Ayaz, M.; Shah, R.; Ali, G.; Haq, I.U.; Ullah, S. Anti-emetic mechanisms of zingiber officinale against cisplatin induced emesis in the pigeon; behavioral and neurochemical correlates. BMC Complement. Altern. Med. 2015, 15, 34. [CrossRef] [PubMed]

132. Hu, X.X.; Liu, X.; Chu, Y.; Chen, W.X.; Zhang, K.W.; Wu, H. Antiemetic activity of effective extract and bioactive compounds in ginger. China J. Chin. Mater. Med. 2016, 41, 904-909.

133. Bossi, P.; Cortinovis, D.; Fatigoni, S.; Rocca, M.C.; Fabi, A.; Seminara, P.; Ripamonti, C.; Alfieri, S.; Granata, R.; Bergamini, C.; et al. A randomized, double-blind, placebo-controlled, multicenter study of a ginger extract in the management of chemotherapyinduced nausea and vomiting (CINV) in patients receiving high-dose cisplatin. Ann. Oncol. 2017, 28, 2547-2551. [CrossRef] [PubMed]

134. Marx, W.; McCarthy, A.L.; Ried, K.; McKavanagh, D.; Vitetta, L.; Sali, A.; Lohning, A.; Isenring, E. The effect of a standardized ginger extract on chemotherapy-induced nausea-related quality of life in patients undergoing moderately or highly emetogenic chemotherapy: A double blind, randomized, placebo controlled trial. Nutrients 2017, 9, 867. [CrossRef] [PubMed]

135. Ernst, E.; Pittler, M.H. Efficacy of ginger for nausea and vomiting: A systematic review of randomized clinical trials. Br. J. Anaesth 2000, 84, 367-371. [CrossRef] [PubMed]

136. Van Breemen, R.B.; Tao, Y.; Li, W. Cyclooxygenase-2 inhibitors in ginger (Zingiber officinale). Fitoterapia 2011, 82, 38-43. [CrossRef]

137. Liao, Y.R.; Leu, Y.L.; Chan, Y.Y.; Kuo, P.C.; Wu, T.S. Anti-platelet aggregation and vasorelaxing effects of the constituents of the rhizomes of Zingiber officinale. Molecules 2012, 17, 8928-8937. [CrossRef]

138. Dormán, G.; Flachner, B.; Hajdú, I.; András, C. Target identification and polypharmacology of nutraceuticals. In Nutraceuticals, 2nd ed.; Gupta, R.C., Lall, R., Srivastava, A., Eds.; Academic Press: Cambridge, MA, USA, 2021; pp. $315-343$.

139. Shah Murad, S.; Niaz, K.K.; Ali, A.; Aslam, A. Ginger and onion: New and novel considerations. Pharm. Pharmacol. Int. J. 2018, 6, 200. [CrossRef]

140. Saxena, R.; Aneja, R. Chapter 18-Multitalented Ginger and Its Clinical Development for Cancer Treatment. In Role of Nutraceuticals in Cancer Chemosensitization; Academic Press: Cambridge, MA, USA, 2018; pp. 351-370. [CrossRef]

141. Karunakaran, R.; Sadanandan, S.P. Zingiber officinale: Antiinflammatory actions and potential usage for arthritic conditions In Bioactive Food as Dietary Interventions for Arthritis and Related Inflammatory; Academic Press: Cambridge, MA, USA, 2019; pp. 233-244. [CrossRef]

142. Li, L.L.; Cui, Y.; Guo, X.H.; Ma, K.; Tian, P.; Feng, J.; Wang, J.M. Pharmacokinetics and tissue distribution of gingerols and shogaols from ginger (Zingiber officinale Rosc.) in rats by UPLC-Q-Exactive-HRMS. Molecules 2019, 24, 512. [CrossRef]

143. Zick, S.M.; Djuric, Z.; Ruffin, M.T.; Litzinger, A.J.; Normolle, D.P.; Alrawi, S.; Feng, M.R.; Brenner, D.E. Pharmacokinetics of 6-gingerol, 8-gingerol, 10-gingerol, and 6-shogaol and conjugate metabolites in healthy human subjects. Cancer Epidemiol. Prev. Biomark. 2008, 17, 1930-1936. [CrossRef]

144. Al-Maharik, N. Isolation of naturally occurring novel isoflavonoids: An update. Nat. Prod. Rep. 2019, 36, 1156-1195. [CrossRef] 
145. Sharma, V.; Ramawat, K.G. Isoflavonoids. In Natural Products: Phytochemistry, Botany and Metabolism of Alkaloids, Phenolics and Terpenes; Springer: Berlin/Heidelberg, Germany, 2013; pp. 1849-1865. [CrossRef]

146. Lecomte, S.; Demay, F.; Ferrière, F.; Pakdel, F. Phytochemicals targeting estrogen receptors: Beneficial rather than adverse effects? Int. J. Mol. Sci. 2017, 18, 1381. [CrossRef]

147. Carbonel, A.A.F.; Simões, R.S.; Girão, J.H.C.; Sasso, G.R.D.S.; Bertoncini, C.R.A.; Sorpreso, I.C.E.; Soares Junior, J.M.; Simões, M.J.; Baracat, E.C. Isoflavones in gynecology. Rev. Assoc. Médica Bras. 2018, 64, 560-564. [CrossRef]

148. Delaruelle, Z.; Ivanova, T.A.; Khan, S.; Negro, A.; Ornello, R.; Raffaelli, B. Male and female sex hormones in primary headaches. J. Headache Pain 2018, 19, 117. [CrossRef]

149. Burke, B.E.; Olson, R.D.; Cusack, B.J. Randomized, controlled trial of phytoestrogen in the prophylactic treatment of menstrual migraine. Biomed. Pharmacother. 2002, 56, 283-288. [CrossRef]

150. Lee, H.; Choue, R.; Lim, H. Effect of soy isoflavones supplement on climacteric symptoms, bone biomarkers, and quality of life in Korean postmenopausal women: A randomized clinical trial. Nutr. Res. Pract. 2017, 11, 223-231. [CrossRef]

151. Ramalingam, M.; Kim, H.; Lee, Y.; Lee, Y.-I. Phytochemical and pharmacological role of liquiritigenin and isoliquiritigenin from radix glycyrrhizae in human health and disease models. Front. Aging Neurosci. 2018, 10, 348. [CrossRef]

152. Nakatani, Y.; Kobe, A.; Kuriya, M.; Hiroki, Y.; Yahagi, T.; Sakakibara, I.; Matsuzaki, K.; Amano, T. Neuroprotective effect of liquiritin as an antioxidant via an increase in glucose-6-phosphate dehydrogenase expression on B65 neuroblastoma cells. Eur. J. Pharmacol. 2017, 815, 381-390. [CrossRef]

153. Li, X.Q.; Cai, L.M.; Liu, J.; Ma, Y.L.; Kong, Y.H.; Li, H.; Jiang, M. iquiritin suppresses UVB-induced skin injury through prevention of inflammation, oxidative stress and apoptosis through the TLR4/MyD88/NF-KB and MAPK/caspase signaling pathways. Int. J. Mol. Med. 2018, 42, 1445-1459. [CrossRef]

154. Zhai, K.F.; Duan, H.; Cui, C.Y.; Cao, Y.Y.; Si, J.L.; Yang, H.J.; Wang, Y.C.; Cao, W.G.; Gao, G.Z.; Wei, Z.J. Liquiritin from Glycyrrhiza uralensis attenuating rheumatoid arthritis via reducing inflammation, suppressing angiogenesis, and inhibiting MAPK signaling pathway. J. Agric. Food Chem. 2019, 67, 2856-2864. [CrossRef]

155. Liu, H.; Wang, J.; Zhou, W.; Wang, Y.; Yang, L. Systems approaches and polypharmacology for drug discovery from herbal medicines: An example using licorice. J. Ethnopharmacol. 2013, 146, 773-793. [CrossRef]

156. Wang, L.; Yang, R.; Yuan, B.; Liu, Y.; Liu, C. The antiviral and antimicrobial activities of licorice, a widely-used Chinese herb. Acta Pharm. Sin. B 2015, 5, 310-315. [CrossRef]

157. Cao, Y.; Wang, Y.; Ji, C.; Ye, J. Determination of liquiritigenin and isoliquiritigenin in Glycyrrhiza uralensis and its medicinal preparations by capillary electrophoresis with electrochemical detection. J. Chromatogr. A 2004, 1042, 203-209. [CrossRef]

158. Kao, T.-C.; Wu, C.-H.; Yen, G.-C. Bioactivity and potential health benefits of licorice. J. Agric. Food Chem. 2014, 62, 542-553. [CrossRef] [PubMed]

159. World Health Organization. WHO Monographs on Selected Medicinal Plants; World Health Organization: Geneva, Switzerland, 1999

160. Farag, M.A.; Porzel, A.; Wessjohann, L.A. Comparative metabolite profiling and fingerprinting of medicinal licorice roots using a multiplex approach of GC-MS, LC-MS and 1D NMR techniques. Phytochemistry 2012, 76, 60-72. [CrossRef] [PubMed]

161. Størmer, F.C.; Reistad, R.; Alexander, J. Glycyrrhizic acid in liquorice—evaluation of health hazard. Food Chem. Toxicol. 1993, 31, 303-312. [CrossRef]

162. Sharma, V.; Katiyar, A.; Agrawal, R. Glycyrrhiza glabra: Chemistry and pharmacological activity. Sweeteners 2018, 87. [CrossRef]

163. Shen, X.-P.; Xiao, P.-G.; Liu, C.-X. Research and application of Radix Glycyrrhizae. Asian J. Pharmacodyn. Pharmacokinet. 2007, 7, 181-200.

164. Fujii, S.; Morinaga, O.; Uto, T.; Nomura, S.; Shoyama, Y. Development of a monoclonal antibody-based immunochemical assay for liquiritin and its application to the quality control of licorice products. J. Agric. Food Chem. 2014, 62, 3377-3383. [CrossRef]

165. Ma, C.; Li, G.; Zhang, D.; Liu, K.; Fan, X. One step isolation and purification of liquiritigenin and isoliquiritigenin from Glycyrrhiza uralensis Risch. using high-speed counter-current chromatography. J. Chromatogr. A 2005, 1078, 188-192. [CrossRef]

166. Wang, H.; Shan, H.; Lü, H. Preparative separation of liquiritigenin and glycyrrhetic acid from Glycyrrhiza uralensis Fisch using hydrolytic extraction combined with high-speed countercurrent chromatography. Biomed. Chromatogr. 2020, 34, e4788. [CrossRef]

167. Gaur, R.; Yadav, K.S.; Verma, R.K.; Yadav, N.P.; Bhakuni, R.S. In vivo anti-diabetic activity of derivatives of isoliquiritigenin and liquiritigenin. Phytomedicine 2014, 21, 415-422. [CrossRef]

168. Su, Q.; Tao, W.; Huang, H.; Du, Y.; Chu, X.; Chen, G. Protective effect of liquiritigenin on depressive-like behavior in mice after lipopolysaccharide administration. Psychiatry Res. 2016, 240, 131-136. [CrossRef]

169. Tao, W.; Dong, Y.; Su, Q.; Wang, H.; Chen, Y.; Xue, W. Liquiritigenin reverses depression-like behavior in unpredictable chronic mild stress-induced mice by regulating PI3K/Akt/mTOR mediated BDNF/TrkB pathway. Behav. Brain Res. 2016, 308, 177-186. [CrossRef]

170. Wang, W.; Hu, X.; Zhao, Z.; Liu, P.; Hu, Y.; Zhou, J. Antidepressant-like effects of liquiritin and isoliquiritin from Glycyrrhiza uralensis in the forced swimming test and tail suspension test in mice. Prog. Neuro-Psychopharmacol. Biol. Psychiatry 2008, 32, 1179-1184. [CrossRef]

171. Jeong, G.S.; Kang, M.G.; Lee, J.Y.; Lee, S.R.; Park, D.; Cho, M.; Kim, H. Inhibition of Butyrylcholinesterase and Human Monoamine Oxidase-B by the Coumarin Glycyrol and Liquiritigenin Isolated from Glycyrrhiza uralensis. Molecules 2020, 25, 3896. [CrossRef] 
172. Yang, E.-J.; Kim, M.; Woo, J.E.; Lee, T.; Jung, J.-W.; Song, K.-S. The comparison of neuroprotective effects of isoliquiritigenin and its Phase I metabolites against glutamate-induced HT22 cell death: Metabolites against glutamate-induced HT22 cell death. Bioorg. Med. Chem. Lett. 2016, 26, 5639-5643. [CrossRef]

173. Yang, N.; Patil, S.; Zhuge, J.; Wen, M.C.; Bolleddula, J.; Doddaga, S.; Goldfarb, J.; Sampson, H.A.; Li, X.M. Glycyrrhiza uralensis flavonoids present in anti-asthma formula, ASHMITM, inhibit memory Th2 responses in vitro and in vivo. Phytother. Res. 2013, 27, 1381-1391. [CrossRef]

174. Straub, I.; Krügel, U.; Mohr, F.; Teichert, J.; Rizun, O.; Konrad, M.; Oberwinkler, J.; Schaefer, M. Flavanones that selectively inhibit TRPM3 attenuate thermal nociception in vivo. Mol. Pharmacol. 2013, 84, 736-750. [CrossRef]

175. Lopez-Castejon, G.; Brough, D. Understanding the mechanism of IL-1ß secretion. Cytokine Growth Factor Rev. 2011, 22, 189-195. [CrossRef] [PubMed]

176. Chi, J.H.; Seo, G.S.; Cheon, J.H.; Lee, S.H. Isoliquiritigenin inhibits TNF- $\alpha$-induced release of high-mobility group box 1 through activation of HDAC in human intestinal epithelial HT-29 cells. Eur. J. Pharmacol. 2017, 796, 101-109. [CrossRef] [PubMed]

177. Huang, Z.; Zhao, Q.; Chen, M.; Zhang, J.; Ji, L. Liquiritigenin and liquiritin alleviated monocrotaline-induced hepatic sinusoidal obstruction syndrome via inhibiting HSP60-induced inflammatory injury. Toxicology 2019, 428, 152307. [CrossRef] [PubMed]

178. Zhou, J.-X.; Wink, M. Evidence for Anti-Inflammatory Activity of Isoliquiritigenin, $18 \beta$ Glycyrrhetinic Acid, Ursolic Acid, and the Traditional Chinese Medicine Plants Glycyrrhiza glabra and Eriobotrya japonica, at the Molecular Level. Medicines 2019, 6, 55 [CrossRef]

179. Vedova, C.D.; Cathcart, S.; Dohnalek, A.; Lee, V.; Hutchinson, M.R.; Immink, M.A. Peripheral interleukin-1 $\beta$ levels are elevated in chronic tension-type headache patients. Pain Res. Manag. 2013, 18, 301-306. [CrossRef]

180. Oliveira, A.B.; Bachi, A.; Ribeiro, R.T.; Mello, M.T.; Tufik, S.; Peres, M. Unbalanced plasma TNF- $\alpha$ and IL-12/IL-10 profile in women with migraine is associated with psychological and physiological outcomes. J. Neuroimmunol. 2017, 313, 138-144. [CrossRef]

181. Rambe, A.S.; Sjahrir, H.; Factor-A, M.M.N. Interleukin-1 and Interleukin-6 Serum Levels and Its Correlation with Pain Severity in Chronic Tension-Type Headache Patients: Analysing Effect of Dexketoprofen Administration. Open Access Maced. J. Med. Sci. 2017, 5, 54. [CrossRef]

182. Zeng, C.; Zhu, D.; You, J.; Dong, X.; Yang, B.; Zhu, H. Liquiritin, as a natural inhibitor of AKR1C1, could interfere with the progesterone metabolism. Front. Physiol. 2019, 10, 833. [CrossRef]

183. Goldstein, M.; Chen, T. The epidemiology of disabling headache. Adv. Neurol. 1982, 33, 377-390.

184. Silberstein, S. Sex hormones and headache. Rev. Neurol. 2000, 156, 30-41. [CrossRef]

185. Lipton, R.B.; Scher, A.I.; Kolodner, K.; Liberman, J.; Steiner, T.J.; Stewart, W.F. Migraine in the United States: Epidemiology and patterns of health care use. Neurology 2002, 58, 885-894. [CrossRef]

186. Silberstein, S.D.; Merriam, G.R. Sex hormones and headache. J. Pain Symptom Manag. 1993, 8, 98-114. [CrossRef]

187. Silberstein, S.; Merriam, G. Sex hormones and headache 1999 (menstrual migraine: Sex hormones and headache 1999 (menstrual migraine). Neurology 1999, 53, S3-S13.

188. Aegidius, K.L.; Zwart, J.A.; Hagen, K.; Dyb, G.; Holmen, T.L.; Stovner, L.J. Increased headache prevalence in female adolescents and adult women with early menarche. The Head-HUNT Studies. Eur. J. Neurol. 2011, 18, 321-328. [CrossRef]

189. Epstein, M.T.; Hockaday, J.M.; Hockaday, T.D.R. Migraine and reproductive hormones throughout the menstrual cycle. Lancet 1975, 305, 543-548. [CrossRef]

190. Chen, M.; Zhang, Q.P.; Zhu, J.X.; Cheng, J.; Liu, Q.; Xu, G.H.; Li, C.F.; Yi, L.T. Involvement of FGF-2 modulation in the antidepressant-like effects of liquiritin in mice. Eur. J. Pharmacol. 2020, 881, 173297. [CrossRef]

191. Ghosh, S. Triterpene structural diversification by plant cytochrome P450 enzymes. Front. Plant Sci. 2017, 8, 1886. [CrossRef]

192. Hordyjewska, A.; Ostapiuk, A.; Horecka, A.; Kurzepa, J. Betulin and betulinic acid: Triterpenoids derivatives with a powerful biological potential. Phytochem. Rev. 2019, 18, 929-951. [CrossRef]

193. Jc Furtado, N.A.; Pirson, L.; Edelberg, H.; Miranda, L.M.; Loira-Pastoriza, C.; Preat, V.; Larondelle, Y.; André, C.M. Pentacyclic triterpene bioavailability: An overview of in vitro and in vivo studies. Molecules 2017, 22, 400. [CrossRef]

194. Tai, T.; Akita, Y.; Kinoshita, K.; Koyama, K.; Takahashi, K.; Watanabe, K. Anti-emetic principles of Poria cocos. Planta Med. 1995, 61, 527-530. [CrossRef]

195. Gapter, L.; Wang, Z.; Glinski, J.; Ng, K.Y. Induction of apoptosis in prostate cancer cells by pachymic acid from Poria cocos. Biochem. Biophys. Res. Commun. 2005, 332, 1153-1161. [CrossRef] [PubMed]

196. Jin, J.; Zhou, R.; Xie, J.; Ye, H.; Liang, X.; Zhong, C.; Shen, B.; Qin, Y.; Zhang, S.; Huang, L. Insights into triterpene acids in fermented mycelia of edible fungus Poria cocos by a comparative study. Molecules 2019, 24, 1331. [CrossRef] [PubMed]

197. Huang, Y.C.; Chang, W.L.; Huang, S.F.; Lin, C.Y.; Lin, H.C.; Chang, T.C. Pachymic acid stimulates glucose uptake through enhanced GLUT4 expression and translocation. Eur. J. Pharmacol. 2010, 648, 39-49. [CrossRef] [PubMed]

198. Split, W.; Szydlowska, M. Headaches in non insulin-dependent diabetes mellitus. Funct. Neurol. 1997, 12, 327-332. [PubMed]

199. Sun, Y. Biological activities and potential health benefits of polysaccharides from Poria cocos and their derivatives. J. Biol. Macromol. 2014, 68, 131-134. [CrossRef] [PubMed]

200. Li, X.; He, Y.; Zeng, P.; Liu, Y.; Zhang, M.; Hao, C. Molecular basis for Poria cocos mushroom polysaccharide used as an antitumour drug in China. J. Cell. Mol. Med. 2019, 23, 4-20. [CrossRef]

201. De Vadder, F.; Mithieux, G. Gut-brain signaling in energy homeostasis: The unexpected role of microbiota-derived succinate. J. Endocrinol. 2018, 236, R105-R108. [CrossRef] 
202. Tretter, L.; Patocs, A.; Chinopoulos, C. Succinate, an intermediate in metabolism, signal transduction, ROS, hypoxia, and tumorigenesis. Biochim. Biophys. Acta BBA-Bioenergy 2016, 1857, 1086-1101. [CrossRef]

203. Levi, M.; Rosselli, M.; Simonetti, M.; Brignoli, O.; Cancian, M.; Masotti, A.; Pegoraro, V.; Cataldo, N.; Heiman, F.; Chelo, M.; et al Epidemiology of iron deficiency anaemia in four European countries: A population-based study in primary care. Eur. J. Haematol. 2016, 97, 583-593. [CrossRef]

204. Nowak, A.; Angelillo-Scherrer, A.; Betticher, D.; Dickenmann, M.; Guessous, I.; Juillerat, P. Swiss Delphi study on iron deficiency. Swiss Med. Wkly. 2019, 149, w20097. [CrossRef]

205. Deen, M.; Hansen, H.D.; Hougaard, A.; Nørgaard, M.; Eiberg, H.; Lehel, S. High brain serotonin levels in migraine between attacks: A 5-HT 4 receptor binding PET study. NeuroImage Clin. 2018, 18, 97-102. [CrossRef]

206. Gasparini, C.F.; Smith, R.A.; Griffiths, L.R. Genetic and biochemical changes of the serotonergic system in migraine pathobiology. J. Headache Pain 2017, 18, 20. [CrossRef]

207. Kim, J.; Wessling-Resnick, M. Iron and mechanisms of emotional behavior. J. Nutr. Biochem. 2014, 25, 1101-1107. [CrossRef]

208. Gür-Özmen, S.; Karahan-Özcan, R. Iron deficiency anemia is associated with menstrual migraine: A case-control study. Pain Med. 2016, 17, 596-605. [CrossRef]

209. Tayyebi, A.; Poursadeghfard, M.; Nazeri, M.; Pousadeghfard, T. Is there any correlation between migraine attacks and iron deficiency anemia? A case-control study. Int. J. Hematol.-Oncol. Stem Cell Res. 2019, 13, 164. [CrossRef]

210. Martínez Francés, A.; Martinez-Bujanda, J.L. Efficacy and tolerability of oral iron protein succinylate: A systematic review of three decades of research. Curr. Med. Res. Opin. 2020, 36, 613-623. [CrossRef]

211. Maevsky, E.; Peskov, A.; Uchitel, M.; Pogorelov, A.; Saharova, N.Y.; Vihlyantseva, E. A succinate-based composition reverses menopausal symptoms without sex hormone replacement therapy. Adv. Gerontol. Uspekhi Gerontol. 2008, $21,298-305$.

212. Ullah, S.; Khalil, A.A.; Shaukat, F.; Sources, S.Y. Sources, extraction and biomedical properties of polysaccharides. Foods 2019, 8 , 304. [CrossRef]

213. Li, Q.; Niu, Y.; Xing, P.; Wang, C. Bioactive polysaccharides from natural resources including Chinese medicinal herbs on tissue repair. Chin. Med. 2018, 13, 1-11. [CrossRef]

214. Chen, Y.-Y.; Chang, H.-M. Antiproliferative and differentiating effects of polysaccharide fraction from fu-ling (Poria cocos) on human leukemic U937 and HL-60 cells. Food Chem. Toxicol. 2004, 42, 759-769. [CrossRef]

215. Zhang, W.; Cheng, S.; Zhai, X.; Sun, J.; Hu, X.; Pei, H. Green and efficient extraction of polysaccharides from Poria cocos FA Wolf by deep eutectic solvent. Nat. Prod. Commun. 2020, 15, 1934578X19900708. [CrossRef]

216. Zhu, H.; Hu, M.; Wang, D.; Xu, G.; Yin, X.; Liu, X.; Ding, M.; Han, L. Mixed polysaccharides derived from Shiitake mushroom, Poriacocos, Ginger, and Tangerine peel enhanced protective immune responses in mice induced by inactivated influenza vaccine. Biomed. Pharmacother. 2020, 126, 110049. [CrossRef]

217. Sun, S.-S.; Wang, K.; Ma, K.; Bao, L.; LIiu, H.-W. An insoluble polysaccharide from the sclerotium of Poria cocos improves hyperglycemia, hyperlipidemia and hepatic steatosis in ob/ob mice via modulation of gut microbiota. Chin. J. Nat. Med. 2019, 17, 3-14. [CrossRef]

218. Ke, R.; Lin, S.; Chen, Y.; Ji, C.; Shu, Q. Analysis of chemical composition of polysaccharides from Poria cocos Wolf and its anti-tumor activity by NMR spectroscopy. Carbohydr. Polym. 2010, 80, 31-34. [CrossRef]

219. Bian, C.; Xie, N.; Chen, F. Preparation of bioactive water-soluble pachyman hydrolyzed from sclerotial polysaccharides of Poria cocos by hydrolase. Polym. J. 2010, 42, 256-260. [CrossRef]

220. Wang, N.; Liu, D.; Guo, J.; Sun, Y.; Guo, T.; Zhu, X. Molecular mechanism of Poria cocos combined with oxaliplatin on the inhibition of epithelial-mesenchymal transition in gastric cancer cells. Biomed. Pharmacother. 2018, 102, 865-873. [CrossRef] [PubMed]

221. Dai, Y.-J.; Wang, H.-Y.; Wang, X.-J.; Kaye, D.A.; Sun, Y.-H. Potential beneficial effects of probiotics on human migraine headache: A literature review. Pain Physician 2017, 20, E251-E255. [CrossRef]

222. Lin, C.-S.; Chang, C.-J.; Lu, C.-C.; Martel, J.; Ojcius, D.M.; Ko, Y.-F. Impact of the gut microbiota, prebiotics, and probiotics on human health and disease. Biomed. J. 2014, 37, 259-268. [PubMed]

223. Hempel, S.; Taylor, S.L.; Solloway, M.R.; Miake-Lye, I.M.; Beroes, J.M.; Shanman, R.; Booth, M.J.; Siroka, A.M.; Shekelle, P.G. Evidence Map of Acupuncture. In Evidence Map of Acupuncture; Department of Veterans Affairs: Washington, DC, USA, 2014.

224. Linde, K.; Allais, G.; Brinkhaus, B.; Fei, Y.; Mehring, M.; Shin, B.-C.; Vickers, A.; White, A.R. Acupuncture for the prevention of tension-type headache. Cochrane Database Syst. Rev. 2016. [CrossRef] [PubMed]

225. Bäumler, P.; Zhang, W.; Stübinger, T.; Irnich, D. Acupuncture-related adverse events: Systematic review and meta-analyses of prospective clinical studies. BMJ Open 2021, 11, e045961. [CrossRef] [PubMed]

226. Lipton, R.B.; Bigal, M.E.; Ashina, S.; Burstein, R.; Silberstein, S.; Reed, M.L.; Serrano, D.; Stewart, W.F.; American Migraine Prevalence Prevention Advisory Group. Cutaneous allodynia in the migraine population. Ann. Neurol. 2008, 63, 148-158. [CrossRef]

227. InformedHealth.org. Using Medication: Topical Medications. Available online: https://www.ncbi.nlm.nih.gov/books/NBK361 $003 /$ (accessed on 14 September 2020).

228. St Cyr, A.; Chen, A.; Bradley, K.C.; Yuan, H.; Silberstein, S.D.; Young, W.B. Efficacy and tolerability of STOPAIN for a migraine attack. Front. Neurol. 2015, 6, 11. [CrossRef]

229. Yuan, R.; Zhang, D.; Yang, J.; Wu, Z.; Luo, C.; Han, L.; Yang, F.; Lin, J.; Yang, M. Review of aromatherapy essential oils and their mechanism of action against migraines. J. Ethnopharmacol. 2021, 265, 113326. [CrossRef] 
230. Villella, S. Herbal management of headache and migraine. Aust. J. Med. Herbal. 2002, 14, 56-62.

231. Kumar, A.; Kadian, R. Migraine Prophylaxis; StatPearls Publishing: Treasure Island, FL, USA, 2021.

232. Chowdhury, D. Tension type headache. Ann. Indian Acad. Neurol. 2012, 15, S83. [CrossRef]

233. Fischer, M.A.; Jan, A. Medication-Overuse Headache; StatPearls Publishing: Treasure Island, FL, USA, 2021. 